\title{
EGY KORA BRONZKORI BÖDÖNHAJÓ NYOMÁBAN
}

\author{
BODNÁR CSABA*
}

\begin{abstract}
1924 őszén a korabeli sajtó egy "párját ritkitó" régészeti felfedezésról adott hírt: a tószegi Laposhalmon folytatott ásatások során egy fából készüllt csónak maradványai kerültek elő. Jelen tanulmány ennek a sanyarú sorsú, a magyarországi bronzkorból máig példa nélkül álló leletnek a történetét járja körül. Az írás kísérletet tesz a csónakkal kapcsolatban rendelkezésre álló különféle források bemutatására, majd azok kritikai elemzésén keresztül a tárgy fizikai jellemzőinek, elökerülési körülményeinek, valamint későbbi sorsának rekonstruálására.
\end{abstract}

Kulcsszavak: bödönhajó, kora bronzkor, Tószeg-Laposhalom, tellstratigráfia, sajtó

In the autumn of 1924, the contemporary press reported an unparalleled archaeological discovery: the remains of a wooden boat were found during the excavations at Tószeg-Laposhalom. The present study reveals the story and rugged biography of this finding which is still unprecedented from the Bronze Age of Hungary. The article attempts to present the various sources available on the boat and, through their critical analysis, to reconstruct the physical characteristics of the object, its archaeological context, and its subsequent history.

Keywords: logboat, Early Bronze Age, Tószeg-Laposhalom, tell stratigraphy, press

A tószegi Laposhalom a Kárpát-medence egyik emblematikus ősrégészeti lelőhelye, amely közel másfél évszázados kutatása során nem egyszer vonta magára a hazai és nemzetközi tudományos világ és közvélemény figyelmét. A tell vastag rétegsora azon túl, hogy meghatározó szereppel bírt a magyarországi bronzkor időrendi alapjainak lefektetésében, alkalmanként meglepő tárgyi leletekkel is szolgált.

A lelőhely neve az 1876. szeptember elején, Budapesten megrendezett VIII. Nemzetközi Ősrégészeti és Embertani Kongresszusnak köszönhetően már felfedezése évében ismertté vált. Az elsó ásatások eredményeit egy, a kongresszus idejére rendezett kiállításon mutatták be az érdeklődőknek. ${ }^{1}$ Ezzel nemcsak tudományos körökben alapozták meg hírnevét, ${ }^{2}$ de a kongreszszus előkészületeit és eseményeit élénk figyelem-

Kézirat beérkezett: 2019. április 9.

* Bodnár Csaba: Szépmúvészeti Múzeum, 1146 Budapest, Dózsa György út 41; ELTE BTK Régészettudományi Intézet, e-mail: bodnar.cs@gmail.com

1 HAMPel 1876, 85-87.

2 CSetneKi JeleniK 1876b, 603; Mestorf 1876, 55-61; PigORINI 1876. mel kísérő korabeli sajtó révén a szélesebb, múzeumlátogató, újságolvasó publikum is hamar tudomást szerzett róla. ${ }^{3}$

A Laposhalom területén a 19. század végén, majd a 20. század első harmadában számos feltárás folyt (1. kép), ${ }^{4}$ amelyek többségét a korabeli újságok is nyomon követték. Az 1910-es és 1920as években, a kutatások legintenzívebb időszakában a fóvárosi és kisebb részben vidéki lapok szinte naprakészen tudósítottak a hol terramareként, hol szihalomként emlegetett lelőhelyen zajló „nagyérdekü és a külföldi tudományos világban is föltünést keltó" ásatásokról..$^{5} \mathrm{~A}$ tell iránti fokozott tudományos érdeklődés folytán időnként még a nemzetközi sajtóban is fel-felbukkant a neve. ${ }^{6}$

1924 késő őszén a korábbi évekhez hasonlóan az újságok az azévi, legújabb eredményekról is

3 Néhány példa: Fövárosi Lapok 13. évf. 149. sz. 1876. július 2. 700; Vasárnapi Ujság 23. évf. 21. sz. 1876. május 21. 332; CSETNEKI JELENIK 1876a; CSETNEKI JELENIK 1876b; Borsszem Jankó 9. évf. 437. sz. 1876. május 21. 9; 9. évf. 444. sz. 1876. július 9. 8.

4 BANNER-BÓNA-MÁRTON 1959. 4-25.

5 RÉTHY 1908, 35.

$6 \quad$ Pl. The Illustrated London News (CHILDE 1927). 


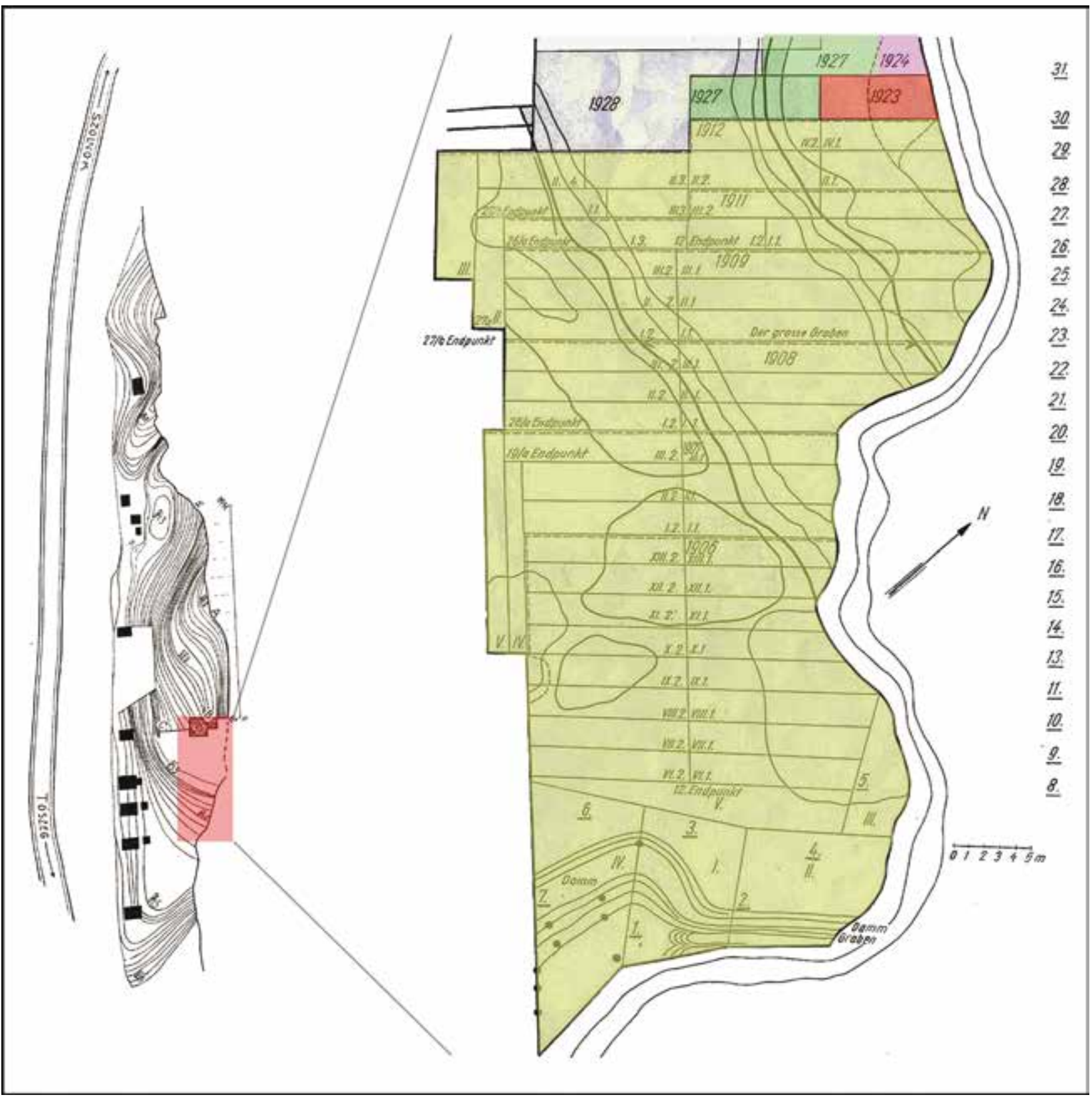

1. kép. Tószeg-Laposhalom és az 1920-as évek feltárásainak helyszíne (BANNER-BÓNA-MáRTON 1959, Abb. 19; ill. SCHALK 1981, 65, Abb. 1 nyomán)

Fig. 1. Tószeg-Laposhalom and the location of the excavations in the 1920s (after BANNER-BónA-MÁRTON 1959, Abb. 19 and SCHALK 1981, 65, Abb. 1)

beszámoltak. A hosszabb-rövidebb novemberi közlemények egy "nagy fontossággal bíró”, "párját ritkító" felfedezésről adtak hírt, miszerint a híres "terramare" telepen az előző évben megkezdett, majd a következő ősszel folytatott ásatások alkalmával egy Magyarországon addig egyedülálló leletre bukkantak. A több méter vastag domb kultúrrétegei közül egy fából készült őskori csónak korhadt maradványai kerültek eló. Jelen tanulmány ennek a sanyarú sorsú, ugyanakkor a magyarországi bronzkorból máig példa nélkül álló leletnek a történetét járja körül, amely a korabeli nagy publicitás ellenére nem vált a szakmai emlékezet szerves részévé, sok körülötte a szakirodalomban a bizonytalanság és pontatlanság. Az írás kísérletet tesz a csónakkal kapcsolatban rendelkezésre álló különféle források bemutatására, majd azok kritikai elemzésén keresztül a tárgy fizikai jellemzőinek, előkerülési körülményeinek, valamint későbbi sorsának rekonstruálására. 


\section{Források}

\section{Újságcikkek}

A csónakkal kapcsolatban rendelkezésre álló forrásaink legbőségesebb csoportját a sajtótermékek, havi- és napilapok alkotják. A felfedezés korabeli sajtóvisszhangjának nagyságát jelzi, hogy egy hangsúlyozottan nem a teljesség igényére törekvő gyújtés során eddig 12 orgánum 17 különböző számában sikerült írott nyomára bukkanni (l. Függelék).

Az újságcikkek a tekintetben, hogy milyen öszszefüggésben említik a csónakot, három csoportba sorolhatók. A cikkek többsége 1924 őszén, közvetlenül a lelet megtalálása után, még a felfedezés lázában született, és annak jelentőségét hangsúlyozza. Első említése a Szózat 1924. október 31-i számából ismert, majd sorra számoltak be róla a nagyobb példányszámú napi- és havilapok. November közepéig legalább kilenc különböző újság hasábjain olvashatott a „világraszóló" leletről a közönség (l. Függelék/1). Miután a megtalálás öröme csillapodott, néhány hónapnyi hallgatást követően legközelebb 1925. március végén írtak róla újra a lapok: az Akadémia egyik felolvasó ülésén Hollendonner Ferenc ismertette a csónak anyagvizsgálati eredményeit (1. Függelék/2). Végül, még ugyanebben az évben, két további említésével találkozunk, mindkét alkalommal egy, a Magyar Nemzeti Múzeum (a továbbiakban: MNM) Érem- és Régiségtárának kutatásait bemutató nagyobb cikk részeként (1. Függelék/3). Úgy túnik, hogy 1925 májusát követően az újságok többé már nem foglalkoztak a csónakkal, ami annak későbbi sorsával állhat összefüggésben.

A felfedezés híre az ásatók, gyaníthatóan az MNM akkori múzeumi őrének, Tompa Ferencnek a kezdeményezésére jutott el a sajtóhoz. A korai beszámolók egy része formai hasonlóságuk alapján valószínúleg egy, az MNM által október 31-én vagy azt megelőzően kiadott sajtóközleményt reprodukál (Budapesti Hírlap, Friss Ujság, Új Barázda november 1-ji számai), míg más cikkek kimondottan Tompával készült interjúk kivonatai (Szózat október 31., Magyarság november 9., Pesti Hírlap november 16., Közmüvelödés novemberi száma), vagy magának Tompának saját kezú írásai (Nemzeti Ujság november 16.). A későbbi említések (Pesti Napló március 25. és május 20.) mögött informátorként a múzeum valemelyik alkalmazottját sejthetjük.

Az újságcikkek között találunk többhasábos, részletes ismertetéseket (pl. Szózat, Magyarság, Pesti Hírlap, Nemzeti Ujság cikkei) és néhány soros, szúkszavú, esetenként ugyanakkor más forrásból nem ismert adatokat egyaránt közlő tudósításokat is (pl. Budapesti Hírlap 1925. március 25.). Bár a cikkek forrásként többnyire a csónakot megtaláló régész(ek)re és a tőlük származó információkra hivatkoznak, ennek ellenére nem egyszer egymásnak ellentmondó megállapításokat is tartalmaznak.

Az újságokban megjelent tévedések és pontatlanságok tisztázása végett már maga Tompa Ferenc, a lelet egyik megtalálója is szükségesnek vélte, hogy tollat ragadjon. A leletről a nagyközönség számára egy rövid tudományos ismertetést írt, amelynek eredeti kéziratát az MNM Régészeti Adattára (a továbbiakban: MNM RA) órzi (MNM RA Tószeg T/I.a.). A hatoldalas, kézzel írt dokumentum, amely számos fontos részletet közöl a csónak kontextusáról és magáról a tárgyról, a Nemzeti Ujság 1924. november 16-i számában olvasható. ${ }^{7}$ Az újságcikk szinte szóról szóra megegyezik a kézirat szövegével, csak az első bekezdésben eszközöltek a lap szerkesztői kisebb változtatást, törölvén Tompa azon megjegyzését, miszerint azért született az írás, mivel a napisajtóban "itt-ott félremagyarázható adatok is napvilágot láttak".

\section{Márton Lajos Tószeg-monográfiájának kézirata}

A csónak előkerülési körülményeivel kapcsolatban fontos támpontokkal szolgál másik felfedezőjének, Márton Lajosnak a tószegi kutatásairól írt nagy, összegző munkája. Az éveken át készült összefoglaló monográfia a szerző korai halála (1934) miatt nem jelent meg, kézirattöredékeit és illusztrációit csak az 1950-es években sikerült áldozatos munkával rendezni és sajtó alá hozni. ${ }^{8}$ A monográfiának több eltérő terjedelmú magyar és német nyelvú, gépelt, ill. kézzel írt példánya is fennmaradt, amelyek többsége a csónakról is tartalmaz egy hosszabb leírást (2. kép). ${ }^{9}$ Bár a publikált szöveg ${ }^{10}$ jórészt húen tükrözi az eredeti kézirat tartalmát, a kézirattöredékeken látható javítások és betoldások némileg árnyalják a lelet felfedezésével és a szöveg keletkezésével kapcsolatos elképzeléseinket. Mivel a kézirat évtizedek alatt formálódott, a csónakkal kapcsolatos szövegrész datálása nem egyértelmú. A leírás több pontatlan és bizonyíthatóan téves tartalmi eleme

\footnotetext{
7 TOMPA 1924; ill. BANNER-BÓNA-MárTON 1959, 24, 116. lábjegyzet is említi, de még mint publikálatlan forrásra hivatkozik.

8 BANNER-BÓNA-MÁRTON 1959.

9 Márton é. n., 60-62.

10 BANNER-BÓNA-MÁRTON 1959, 40, 133. lábjegyzet.
} 


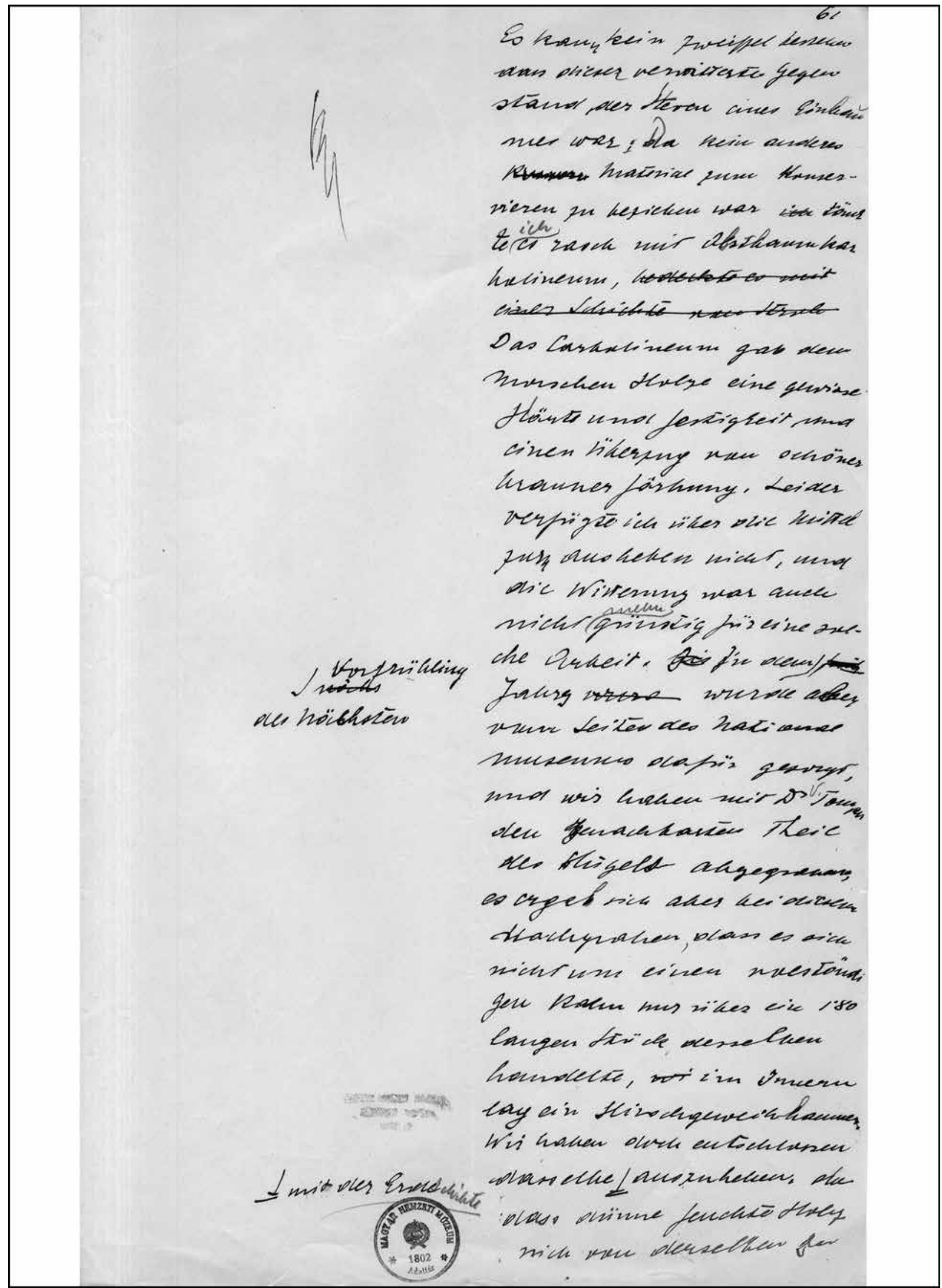

2. kép. A csónak leírásának részlete Márton Lajos Tószeg-monográfiájának német nyelvú kéziratában (MÁRTON é. n., 61, MNM RA Ha 2002.XII.136)

Fig. 2. Detail from the description of the boat in the German-language manuscript of Lajos Márton's Tószeg-monograph (MÁrTON é. n., 61, MNM RA Ha 2002.XII.136) 
(1. alább) inkább arra utal, hogy azt Márton évekkel a felfedezés után, emlékezetból írhatta, és csak utólag illesztette be aktuális helyére.

\section{Ásatási dokumentációk}

(rajzok, fényképek, feljegyzések)

Az újságcikkeken és a feltárók kéziratain túl elsődleges forrásaink az 1920-as évek tószegi ásatásainak fennmaradt dokumentációi. A főként az MNM adattárában, kisebb részben a Museum of Archaeology and Anthropology, University Cambridge (a továbbiakban: CUMAA) és a Groningen Institute of Archaeology (a továbbiakban: GIA) archívumaiban őrzött ásatási naplók, tárgylisták, felszín- és metszetrajzok, fényképek, egyéb dokumentumok közvetve vagy közvetlenül nagy segítséget nyújtanak a lelet régészeti kontextusa és fizikai vonásai körüli bizonytalanságok tisztázásában.

Bár a következő fejezetek részletesen ismertetik az imént felsorolt dokumentumokat, kiemelt figyelmet érdemel az az MNM RA által őrzött négyzetrácsos füzet (MNM RA Tószeg T/I.a. 8 füzet: „Vegyes tárgyak”), amely a lelet formájára és méreteire vonatkozóan a legfontosabb kútfőnk, lévén az 1920-as évek ásatásainak több szelvényfalmetszete mellett számos régészeti jelenség vázlatát, köztük két oldalon bizonyosan a csónak rajzait is tartalmazza (5. kép). Utóbbi ceruzarajzok különös értéket képviselnek, mivel egyedülálló módon részleteiben ábrázolják a leletet, sőt annak méreteit is feltüntetik. A rajzok készítőjét a mellettük szereplő betúk és számok írásmódja alapján Tompa Ferenccel azonosíthatjuk. Keletkezésük pontos időpontja nem ismert, valószínúleg az ásatást követően, 1924 novemberében készültek.

\section{A Magyar Nemzeti Múzeum leltárkönyve}

A csónakot a Tószeg-Laposhalmon 1924 októberében folyt ásatás leletanyagának részeként, a 1924. évi 42. tétel utolsó, 74. darabjaként beleltározták az MNM gyújteményébe. Az MNM leletárkönyve a következő információkat tartalmazza a leletről: „Vájt csónak egyik fele, $187 \mathrm{~cm}$. hosszú, legnagyobb szélessége $67 \mathrm{~cm}$." A leltárkönyvi adatok szerint a nyilvántartásba vétel 1924. november 20-án történt, és a kézírás alapján ezt szintén Tompa Ferenc jegyzi. A 1958. évi, első dokumentált revízió során a tárgynak már nem volt nyoma a gyújteményben.

\section{Hollendonner Ferenc tanulmánya}

További nélkülözhetetlen forrásunk a csónakról a Királyi József Múegyetem (ma: Budapesti Múszaki- és Gazdaságtudományi Egyetem) egykori tanárának, a mikroszkopikus faszénvizsgálat (anthrakotómia) úttörő kutatójának, Hollendonner Ferencnek a Matematikai és Természettudományi Értesítóben megjelent egyik tanulmánya, amelyben beszámolt a Tószegen talált fák, faszenek vizsgálatának eredményéről. A szerző meghatározta a csónak anyagát és további adatokat is közölt róla. ${ }^{11}$

\section{A csónak a későbbi szakirodalomban}

Az újságok híradásait, majd az anyagvizsgálatára vonatkozó első eredményeket követően a régészeti szakirodalomban egészen az 1950-es évekig nem találkozunk a lelet említésével. Márton Lajos és Tompa Ferenc halála után feltehetően Banner János az első, aki felfigyel rá. ${ }^{12}$ A lelettel kapcsolatban még felkutatható adatok ismertetésére az Acta Archaeologica 10. számában, a Márton Lajos korábbi tószegi kutatásait bemutató nagy tanulmány részeként került sor. A cikkben publikálták a csónak Márton kéziratában olvasható leírását, ${ }^{13}$ a Márton által rekonstruált stratigráfiai helyzetét, ${ }^{14}$ valamint Tompa Ferenc ceruzarajzainak némelyikét, ${ }^{15}$ a források kritikai értékelése ugyanakkor elmaradt. A cikk több pontatlanságot is tartalmaz: a lelet itt közölt rétegtani helyzete utólag tévesnek bizonyult (l. alább), illetve a 40.2. képen látható tárgyról is kiderült, hogy az nem a csónakot, hanem egy, az 1927. évi feltárás déli szelvényének 9. szintjén előkerült épület fagerendáit ábrázolja. ${ }^{16}$

A csónak forrásainak újbóli áttekintése a régészeti szakirodalomban ezt követően nem merült fel. Bár magyarországi bronzkort érintő publikációkban egy-egy hivatkozás szintjén alkalmanként felbukkan, ${ }^{17}$ a lelet nem vált széles körben ismertté, az őskori Európa vízi közlekedési esz-

\footnotetext{
11 HOLlendonNer 1925, 199-201, 203.

12 BANNER 1955, 142.

13 BANNER-BÓNA-MÁRTON 1959, 40.

14 BANNER-BÓNA-MÁRTON 1959, 56, Abb. 25

15 BANNER-BÓNA-MÁRTON 1959, 81, Abb. 40.2-3.

16 Eredeti rajzát 1. MNM RA Tószeg T/I.a. 8 füzet: „Vegyes tárgyak"; vö. BANNER-BónA-MÁrTon 1959, 63, Abb. 30, Taf. VII.3; HEYWORTH 1984, 45, Sheet I.

17 BÓNA 1975, 164 (tévesen Füzesabony rétegből), DufFY 2008, 126; ORAVECZ 2013, 10; DufFy 2014, 105.
} 


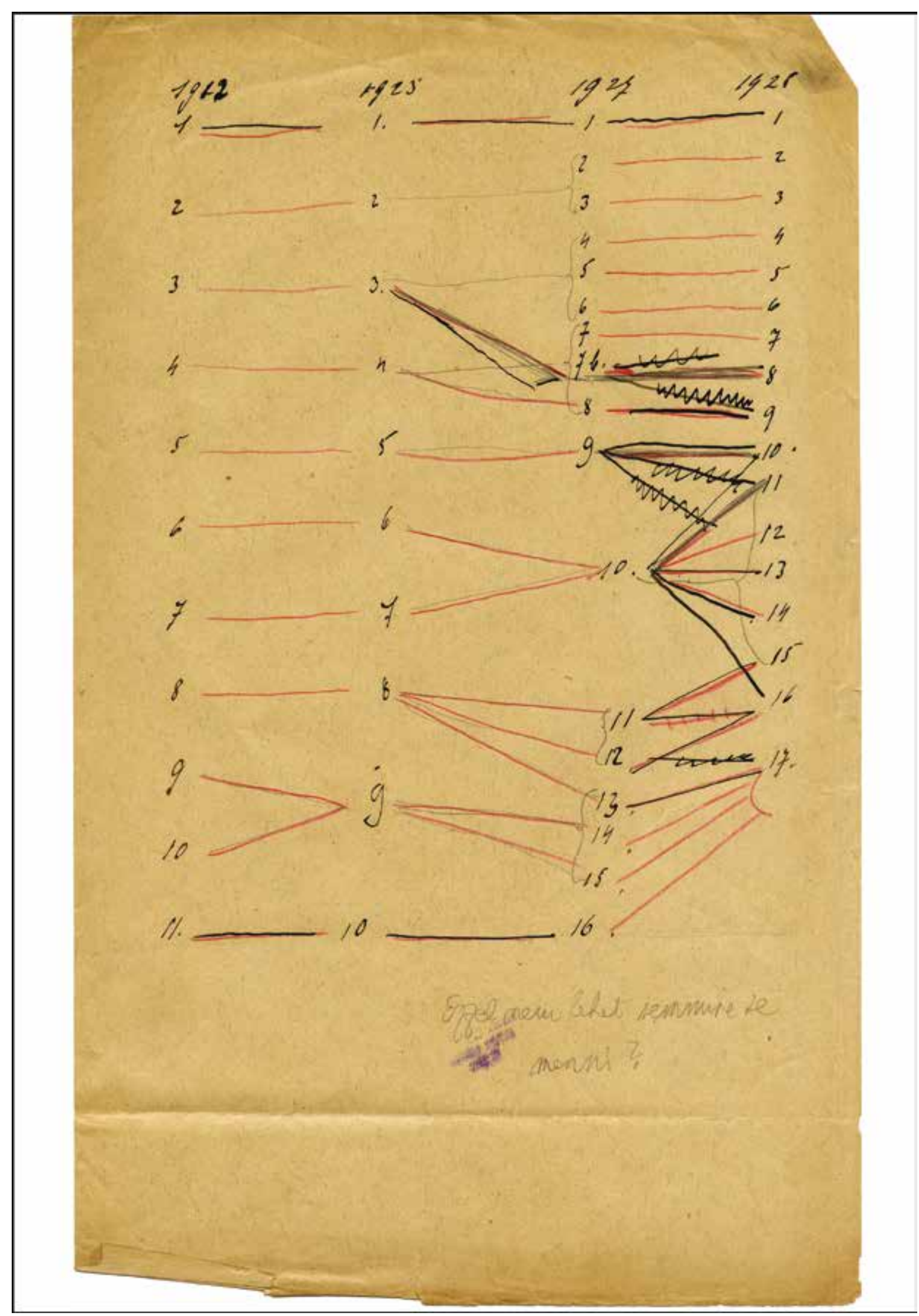

3. kép. Az 1912 és 1928 között folytatott feltárások során elkülönített települési szintek száma és egymáshoz viszonyított helyzete (MNM RA Tószeg T/I.a)

Fig. 3. Number and relative position of the settlement levels separated during the excavations between 1912 and 1928 (MNM RA Tószeg T/I.a) 
közeiről írt nagyobb összegző tanulmányok, monográfiák szerzői nem tesznek róla említést. ${ }^{18}$

\section{A lelet története}

\section{Tószegi kutatások az 1920-as években}

A tószegi tell kutatásának legintenzívebb időszaka az 1906 és 1928 közötti negyed évszázad, amely során számos ásatás zajlott a Laposhalom akkor még viszonylag ép déli részén (1. kép). Az első világháborút megelőző évtizedben a feltárások az MNM akkori őrének, Márton Lajosnak a vezetése alatt, a múzeum anyagi támogatásával történtek, a háborút követó ínséges időszak viszont új feltételeket szabott. A korábbi gyakorlattól eltérően külföldi intézményeket vontak be a kutatásba, amelyek a feltárt leletanyag egy részéért cserébe pénzügyi segítséget nyújtottak, és így, noha kisebb léptékben, de lehetóvé tették a folytatást. ${ }^{19}$

Az 1920-as években négy alkalommal végeztek ásatást a lelőhelyen $(1923,1924,1927,1928),{ }^{20}$ ezek lefolyása és kimenetele ugyanakkor ma már csak nagy vonalakban rekonstruálható. Az ásatások terepi dokumentációja hiányos, a metszet- és felszínrajzok, a feltárás eseményeit rögzítő naplók csak részben maradtak fenn. Az ásatók eredményeiknek csak töredékét publikálták, a feltárásokról elózetes beszámolók nem jelentek meg. Jórészt csak a korabeli sajtó tudósításai, a feltáráson részt vevők levelezései, illetve késóbbi munkákban közölt információk alapján próbálhatunk meg képet alkotni a négy évad történéseiról.

A nemzetközi érdeklódésre is számot tartó lelóhelyen az első világháború után először 1923ban nyílt mód újabb feltárásra, amikor a groningeni Biologisch-Archeologisch Instituut (a továbbiakban: BIA, ma GIA) szerény anyagi hozzájárulásával egy $\mathrm{kb} .8 \times 3 \mathrm{~m}$ kiterjedésú szelvényt nyitottak közvetlenül az 1912-es ásatás felszínétól északra, a halom keleti szélén (1. kép). ${ }^{21} \mathrm{~A}$ feltárás tiszteletbeli vezetóje Márton Lajos volt, holland részről Albert Egges van Giffen, az MNM részéről pedig Bella Lajos, Tompa Ferenc és Hillebrand Jenő bizonyosan részt vett rajta.

18 PARet 1930, 111; Arnold 1995; ARnold 1996; LANTing 2000, 644; ROGERS 2009.

19 GYÖRI 1924; SCHALK 1981, 68-69; BÓNA 1992, 104; LEIGHTONSøRENSEN 2004, 46-49, 52-54.

20 A Tompa 1937, 71 és Mozsolics 1952, 37 által említett 1925-ös ásatás nem dokumentálható, minden bizonnyal tévedés.

21 BANner-Bóna-Márton 1959, 23-24, Abb. 19; SCHAlK 1981, 68-69.
A szeptember végén, október elején ${ }^{22}$ lefolytatott rövid ásatásról nem sokat tudunk, a Márton által vezetett ásatási napló a második nap után (szeptember 28.) félbemaradt. ${ }^{23} \mathrm{Az}$ eredeti dokumentációból az MNM RA 13 felszínrajzot ${ }^{24}$ (12. kép) és legalább öt, a szelvény északi faláról készült, a feltárás és értelmezés különböző állomásait mutató metszetrajzot ${ }^{25}$ (10. kép) óriz. A feltárt jelenségekről további forrásunk Márton fent említett kézirata és az annak részét képező összesítő felszínrajzok (Horizontalprofile), ahol a szerző az 1923. évi ásatás eredményeit a következő évek megfigyeléseivel összedolgozva, települési szintenként ábrázolta. ${ }^{26} \mathrm{Az}$ 1923-ban feltárt szintek száma nem egyértelmú: míg Banner szerint ekkor még csak 10 szintet választottak szét ${ }^{27}$ (1. 3. kép), ennek ellentmond a fennmaradt eredeti felszínrajzok száma (13), valamint Márton összesítő felszínrajzai, ahol mind a 16 szint rajzán látható régészeti objektum az 1923. évi szelvényben. Az ásatás anyagából az MNM leltárkönyvébe egyetlen darabot se vezettek be, a leletanyagot valószínúleg teljes egészében a groningeni BIA-nak küld ték el. ${ }^{28}$

A következő feltárásra 1924 őszén, az MNM leltárkönyvének tanúsága szerint október 16 . és 23. között került sor. A szintén rövid, egyhetes feltárás, amelyen Márton Lajos, Tompa Ferenc és Bella Lajos is részt vett, feltehetően Tompa és Márton közös irányításával, csekély hazai forrásból valósult meg. ${ }^{29}$ A kisméretú, kb. 3,7-3,9×2,52,9 m kiterjedésú szelvényt (Márton Lajos összesító térképe és korabeli fényképek alapján) közvetlenül az előző évi feltárás helyszínétől északra, a tell Tisza által évről évre alámosott keleti falában jelölték ki (1. kép; 4. kép 1). A feltárásról igen szegényes dokumentáció áll rendelkezésre. Âsatási napló nem készült, a szelvény északi faláról metszetrajzot nem ismerünk. Az elókerült jelenségekről csupán néhány korabeli (Márton Lajos véleményével ${ }^{30}$ ellentétben szerencsésen megmaradt) fényképfelvétel ${ }^{31}$ (4. kép), illetve

22 Van Giffen Groningenben őrzött naplója alapján talán szeptember 27. és október 3. között (SCHALK 1981, 67, 21. lábjegyzet).

23 MNM RA Tószeg T/I.a. 1. füzet.

24 MNM RA Tószeg T/I.a. 18. mappa.

25 MNM RA Tószeg T/I.a. 8. füzet; Tószeg 1-2. T.I.a. ltsz.: 4149; ill. BANNER-BÓNA-MÁRTON 1959, Abb. 17, Profil 31.

26 MNM RA Tószeg 1-2. T.I.a. ltsz.: 4149; vö. BANNER-BÓNAMÁRTON 1959, 36-45, 51-77, Abb. 22-37.

27 BANNER-BÓNA-MÁrTON 1959, 24.

28 BANNER-BÓNA-MÁrTON 1959, 111. lábjegyzet; SCHALK 1981, 81.

29 HÓMAn 1929, 62; BANNER-BÓNA-MÁrton 1959, 24, Abb. 19.

30 BANNER-BÓNA-MÁRTON 1959, 40, 133. lábjegyzet.

31 MNM RA Tószeg T/I.a., MNM RA Stanczik Ilona hagyatéka, 1-2.T.I.1. 


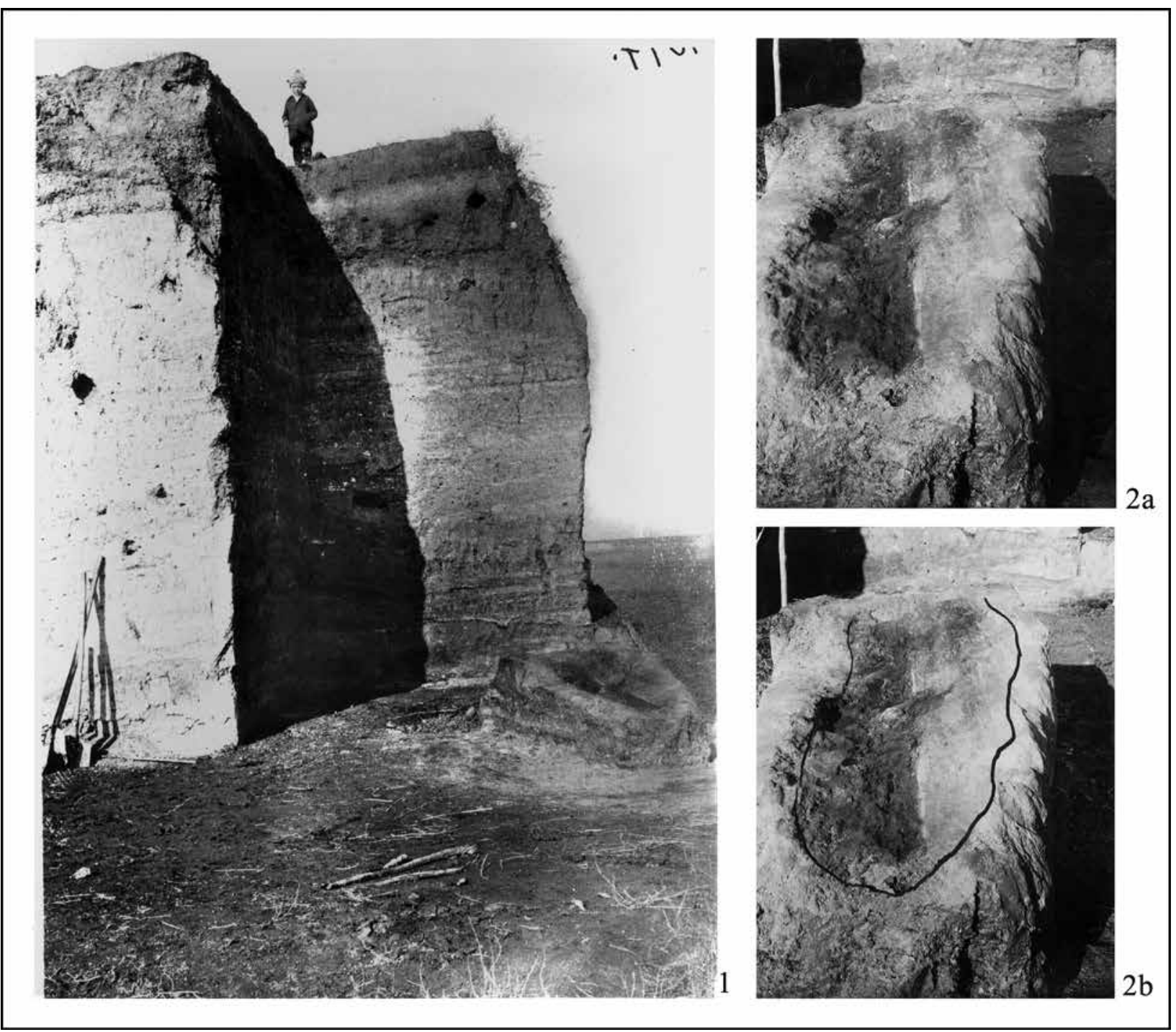

4. kép. A csónaklelet feltárását ábrázoló fényképfelvételek az 1924. évi ásatásról: 1. Az 1924. évi rétegsor, tövében a csónakkal; 2a-b. A csónakot tartalmazó földtömeg [2b fotón a csónak (ismeretlen kéz által) körberajzolt, feltételezett kontúrja látható] (MNM RA Tószeg T/I.a)

Fig. 4. Photographs of the 1924 excavation depicting the exploration of the boat: 1 . Stratigraphy of the 1924 excavation: the boat is located at the bottom; $2 a-b$. The earth mass containing the boat [Fig. $2 b$ shows the assumed contour of the boat (drawn by an unknown hand)] (MNM RA Tószeg T/I.a)

Tompa Ferenc terepen készített, kis méretarányú, vázlatos felszínrajzai és az azokhoz kapcsolódó megjegyzések $^{32}$ (11. kép) alapján alkothatunk képet. Márton Lajos kéziratában az 1923-as ásatáshoz hasonlóan az 1924-es feltárás eredményei is szerepelnek, ${ }^{33}$ az összesítő felszínrajzain ábrázolt jelenségek ugyanakkor nem mindig egyeznek meg a Tompa Ferenc vázlatrajzain látható megfigyelésekkel. Az 1924-es ásatáson Tompa rajzai alapján 16 szintet különítettek el és első ízben rögzítették azok mélységadatait is. Mivel a

32 MNM RA Tószeg T/I.a. Tompa feljegyzései 1924 Tószeg (kisméretü, négyzetrácsos füzet).

33 BANNER-BÓNA-MÁRTON 1959, 36-45, 51-77, Abb. 22-37. feltárás költségeit ez esetben sikerült az MNMnek előteremtenie, a leletek a múzeum gyứjteményébe kerültek, ahol még ez év novemberében leltári számot kaptak.

Ugyanebben az évtizedben két alkalommal történt még ásatás a lelőhelyen, mindkétszer nemzetközi együttmúködések keretében: 1927. április 21. és május 7. között a Cambridge University Museum of Archaeology and Ethnology (ma: CUMAA) finanszírozásával és szakmai támogatásával, ${ }^{34}$ egy évre rá, 1928 máju-

34 Childe 1927; Hóman 1929, 74; Heyworth 1984; LeightonSøRENSEN 2004. 
sában pedig újból a groningeni BIA anyagi segítségével folytatták a megkezdett munkát. ${ }^{35} \mathrm{Az}$ 1927-es ásatás során a megelőző évek feltárási helyszíneitól nyugatra két szelvényt nyitottak $(8 \times 3 \mathrm{~m}$, illetve $7,5 \times 3 \mathrm{~m})$, amelyeket 1928-ban egy nagyobb felületre bóvítettek $(7 \times 10,5 \mathrm{~m}$, illetve $4,5 \times 3 \mathrm{~m})(1$. kép). A két feltárás dokumentációját ma részben az $\mathrm{MNM}^{36}$ részben a cambridge-i $^{37}$ (1. 9. kép) és a groningeni egyetem ${ }^{38}$ archívumaiban őrzik. A kiásott tárgyak a két külföldi intézmény gyújteményeit gyarapították.

\section{A „zsíros földtömeg" előkerülése}

A csónaklelet előkerülésének körülményeit, ill. későbbi sorsát illetően a források nem minden részlet tekintetében értenek egyet, így az események itt vázolt láncolata csupán egy, noha talán a legvalószínúbb a lehetséges forgatókönyvek közül.

A csónak megtalálásáról több forrás is tudósít. A felfedezés legteljesebb leírását Márton Lajos kéziratában olvashatjuk, ${ }^{39}$ de az eseményről több újság is részletesen beszámolt (pl. Pesti Hírlap, Nemzeti Ujság, Magyarság). Forrásaink egyöntetúen arról írnak, hogy a csónakot két részletben, két egymást követő évben találták. Első darabjára, egy lapos, keskeny, erősen korhadt fatárgyra 1923 őszén, a groningeniekkel közösen folytatott ásatás vége felé, több méternyi kultúrréteg eltávolítása után lettek figyelmesek. A Magyarság tudósítása szerint „,a mélyre ásott domb egyik zugában [Márton Lajos] észrevett egy különös alaku földtömeget s amikor óvatosan föltárta, kitünt, hogy egy korhadó fiatal kőkori kéregcsónak szétmálló darabjai hevernek ott." A felfedezés tényéról az ásatási dokumentációban csupán néhány vázlatos metszetrajz tanúskodik (10. kép), a terepen készült felszínrajzokon a leletet nem jelölték. Az előkerülés pontos dátumára vonatkozóan nem maradt fenn adat, de a van Giffen feljegyzéseiből kikövetkeztethető időrend alapján október első napjaiban történhetett.

Megtalálásakor a lelet már erősen morzsolódott, így megpróbálták még ott a helyszínen konzerválni. Minthogy más konzerváló anyag nem volt beszerezhetó, karbolineummal (egy karbolsav-tartalmú olajjal) itatták át, amely a szétmálló fának erősebb tartást és keménységet kölcsön-

35 Hóman 1929, 75; TOMPa 1937, 71; Schalk 1981, 68-69, 82.

36 MNM RA Tószeg T/I.a. 1. füzet, ill. 18. mappa, vö. BANNERBÓNA-MÁrTon 1959, Abb. 17. Profil 31, 51-77, Abb. 22-37, Taf. II.4, VII.3.

37 MMA LL1/4/2, vö. HeYworTH 1984, 28-67, Sheet A-P.

38 L. Tompa 1937, Abb. 3, 70, Abb. 4, Taf. 36, 37; SCHAlK 1981, 65, Abb. 1, 66, Abb. 2.

39 Márton é. n., 60-62. zött. Sajnos mivel már az ásatás vége felé jártak, és sem megfelelő eszköz nem állt rendelkezésre, amellyel kiemelhették volna, sem az időjárás nem kedvezett a munka meghosszabbításának, a tárgyat nem bontották ki. A teljes feltárást, feltehetően bízva a konzerváló anyag minőségében, a következő évre halasztották. ${ }^{40}$

Az újságcikkek híradásaiból tudjuk (pl. Szózat, Magyarság, Nemzeti Ujság stb.), hogy hiába az előzó évi karbolineumos védelem, a Tisza ellen, ha „letépi láncát”, ez nem segít. Az 1924. tavaszi áradás a csónak már kibontott felét vagy annak egy részét (az újságok adatai szerint egy $40 \mathrm{~cm}$-es darabját) magával vitte.

A „maga nemében páratlan” lelet jelentőségét Márton Lajos és az ásatáson jelen lévő Tompa Ferenc egyaránt felismerte, így miután utóbbi közbenjárására az MNM-nek sikerült némi forrást előteremtenie a munka folytatására, „Hóman Bálint dr., a Magyar Nemzeti Muzeum fóigazgatója azzal a megbizással küldte ki Tompa Ferenc dr. arheológust, emelje ki a megmaradt darabot a dombfalból és szállíttassa fel a Nemzeti $\mathrm{Mu}$ zeumba." (Magyarság) Noha a visszatérés időpontjaként a Magyarság 1924 nyarát, Márton pedig ugyanezen év kora tavaszát említi, ${ }^{41}$ 1924ben dokumentálhatóan csak egy ásatás folyt a Laposhalmon, ezért a csónak megmaradt részének feltárására is 1924. október 16. és 23. között kellett, hogy sor kerüljön. Mivel az újságcikkek többsége és az MNM leltárkönyve egyaránt az őszi időpontot támogatja, az évekkel a feltárás után született Márton-kéziratban szereplő kora tavaszi dátum, amely nem mellesleg a szövegben egy utólagos betoldás (2. kép), feltehetően a szerzó csalóka emlékezetének termése.

Bár az 1924-es ásatás célkitúzéseit és lefolyását ma már nehéz rekonstruálni, a korabeli híradások fényében nem kizárt, hogy annak éppen az előző évben elókerült csónaklelet kibontása és további pusztulástól való megóvása lehetett egyik elsődleges motivációja. A rövid, leletmentő feltárás e tekintetben sikeresnek mondható, eredményeként ugyanis a csónak egy további, kb. 1,8 méteres darabját hozták felszínre. A felfedezést egy vázlatos felszínrajz (11. kép 2) mellett több fénykép (4. kép) és tárgyrajz (5. kép) is tanúsítja.

Az újságok és az ásatók beszámolói egyaránt arról informálnak, hogy mivel a tárgy nagyobbik részét szintén erôsen korhadt állapotban találták meg, és amint megpróbáltak azt a befogadó nedves földrétegból kibontani, elkezdett széttöredezni, úgy döntöttek, hogy feltárását alkalmasabb körülmények közt, az MNM-ben folytat-

40 Márton é. n., 61.

41 Márton é. n., 61. 
ják.42 A „zsíros földtömeget” még ott helyben karbolineummal impregnálták (Magyarság), majd „kockánkint” körbevágták (kifúrészelték) (Szózat) és egy „előre elkészített egyik oldalán nyitott ládát" húztak rá oly módon, hogy "utána óvatosan aláásták vastagon a földet, s a láda hatodik oldalát alulról erósítették meg" (Pesti Hírlap). A nagybecsú leletet a rossz idő ellenére ${ }^{43}$ feltehetően az ásatás utolsó napján (október 23-án) sikerült kiemelni. A ládát ezt követően egy „szalmával kirakott teherautón hozták Budapestre, ahol a rekonstrukció és a további vizsgálatok megejtéséig a muzeum kőrégiségtára folyósóján helyezték el" (Szózat).

\section{A lelet későbbi sorsa}

Későbbi sorsa a jelenleg rendelkezésre álló források tükrében kevésbé egyértelmú. Beszámolóik alapján sejthető, hogy a felfedezését követő kéthárom hétben a csónakot több újságíró személyesen is megtekintette, ${ }^{44}$ miközben az még két méter hosszú, vastag deszkaládájában a „Magyar Nemzeti Múzeum földszintjének boltíves folyósói alatt" hevert és tisztítására, konzerválására, felmontírozására várt. A várakozás időtartama nem ismert, a Pesti Hírlap és a Nemzeti Ujság november 16-án megjelent cikkeinek írásakor a konzerválás és a preparálás még csak terv volt. Ezzel szemben biztosan tudjuk, hogy a lelet november 20-án „vájt csónak egyik fele” megnevezéssel leltári számot kapott (l. fentebb), de hogy ez már megtisztított, preparált állapotában vagy még zsíros földtömegként törtent meg vele, az az MNM leltárkönyvi bejegyzéséből nem derül ki. Időközben, hogy anyagáról és készítésének módjáról pontosabb képet alkothassanak, a csónakot „alapos chémiai vizsgálatok alá” vetették (Szózat). Anyagából mintát vettek, amelyet a Múzeum egykori Növénytani Tára útján Hollendonner Ferencnek, a budai Paedagogium akkori tanárának küldtek el (Magyarság). A mintavétel időpontja szintén ismeretlen, feltehetően még a konzerválás előtt került rá sor. Az eredményeiról Hollendonner először 1925. március 23án, az MTA egyik felolvasó ülésén számolt be (1. Függelék/2), majd még ugyanebben az évben részletesen publikálta is azokat. ${ }^{45}$

A tisztítás és konzerválás folyamatáról és eredményéről adataink ellentmondásosak. A Pesti Hirlap így vázolta fel a késóbbi teendőket: miu-

\footnotetext{
42 MÁrton é. n., 61-62.

43 MÁRTON é. n., 61.

44 L. Szózat (október 31.), Magyarság (november 9.).

45 HOLLENDONNER 1925, 199-201, 203.
}

tán „óvatosan leszedik a csónakra rétegeződött földet, [és] karbolineummal bekenik, mely tudvalevóen profilaktikus szere a fatetveknek és a fakéreg romlását, korhadását előidéző savaknak”, "különböző anyagokkal preparálják még tartósabbá s hiányos részei rekonstruálásával kerül a Nemzeti Muzeum üvegszekrénye alá." Forrásaink szerint a konzerválás és preparálás során többféle anyagot is felhasználtak. Még Tószegen a kiemelés elótt karbolineummal (Magyarság), majd feltehetően már Budapesten parafinnal itatták át (Szózat). A Pesti Napló március 25-i száma hónapokkal a felfedezés után arról ír, hogy a csónak „stearinnal gondosan preparálva [...] a legféltettebb darabját képezi a múzeumnak". A konzerválás módja és minősége tekintetében gyökeresen eltérő kép rajzolódik ki Márton Lajos kéziratából, amely szerint az előzetes tisztítás után a konzerválással megbízott (anonim) restaurátornak „sajnos az a szerencsétlen ötlete támadt, hogy a földhöz ragadó fát sellakkal itassa át. A sellak egy utálatos, üveges kérget képzett és bár eloldotta a fát a földtől, az lassan szétmorzsolódott". ${ }^{46}$

Függetlenül attól, hogy hitelt adunk-e (az emlékezetében többször csalatkozó) Márton Lajos kijelentésének a rosszul sikerült konzerválással kapcsolatban, kézirata vonatkozó részeinek írásakor (l. fentebb) a csónak valószínúleg már nem létezett, illetőleg - ami kevésbé valószínú - neki erról már nem volt tudomása. A csónak utolsó említése a Pesti Napló 1925. május 20-i számából ismert; ezt követóen a napisajtó már nem foglalkozott vele, ami csak részben indokolható ugyanakkor a szenzációk sajátos, rövid életû́ természetével. A lelet tudományos jelentősége folytán, amennyiben preparálása után a terveknek megfelelően „a Nemzeti Muzeum üvegszekrénye alá" kiállították és a nagyközönség számára elérhetővé tették volna, valószínúleg az újságírók figyelmét sem kerülte volna el (ahogy maga a lelóhely is gyakran feltúnik még a sajtóban a következő években ${ }^{47}$ ). A Pesti Napló 1925. március 25-i cikkének szerzője (B.B.), noha szavai alapján nem világos, hogy a tárgyat személyesen is látta-e, még úgy ír a csónakról, mint az MNM gyújteményének legféltettebb darabja, így az ekkor talán még létezett. Mindenesetre, ha egy darabig őrizte is még a múzeum, az 1958-as revízió során fizikai nyoma már nem volt. Hogy a háborús pusztításnak esett-e áldozatul, mint az 1924-es ásatás leletanyagának nagy része, vagy még jóval korábban

\footnotetext{
46 MárTon é. n., 62.

47 L. Az Est 18. évf. 100. sz. 1927. május 4. 10; Pesti Hírlap 49. évf. 105. sz. 1927. május $10.10 \mathrm{stb}$.
} 
a gondatlan konzerválás miatt ment tönkre, esetleg más oka volt eltûnésének, a rendelkezése álló források alapján nehéz eldönteni. További levéltári és sajtótörténeti dokumentumok feltárása újabb adatokkal szolgálhat a csónak utolsó hónapjairól, esetleg éveiről.

\section{A „leletek koronája" - a tárgy leírása a források tükrében}

Állapot

Forrásaink egyetértenek abban, hogy a lelet 1923ban megtalált, rövidebb darabja a Tisza áradásának következtében teljesen elpusztult, hosszabb részlete pedig olyan állapotban került elö, hogy „egyszerú érintésre porladt széjjel” (Szózat).48 Tompa szerint „,szerencsés megmaradását annak köszönhetjük, hogy a Tisza áradása következtében iszapréteg temette el, a később rárakodó kultur- és iszaprétegek pedig többször is viz alatt állottak" ${ }^{49}$ Noha ezen rétegek súlya a lelet állapotát erősen befolyásolta [„,lenyomták, deformálták, ellapították" (Szózat)], rossz megtartása több forrás szerint is csak részben magyarázható posztdepozíciós képződési folyamatokkal. A belsejében látható szabálytalan lyukak kapcsán felmerült, hogy a tárgy már eleve rongált, sérült állapotban kerülhetett föld alá (Nemzeti Ujság, Pesti Hirlap).

\section{Méret}

A lelet méreteit tekintve különféle adatokkal találkozunk. Az 1924-ben kiásott rész hosszúságát illetően a leírásokban leginkább $187 \mathrm{~cm},{ }^{50}$ néha $180 \mathrm{~cm},{ }^{51}$ egy alkalommal pedig $108 \mathrm{~cm}^{52}$ szerepel, noha ez utóbbi adat valószínúleg sajtóhiba, elírás eredménye. Amennyiben a legvalószínúbb értékhez $(187 \mathrm{~cm})$ hozzáadjuk az előző évi, elsodort darab $40 \mathrm{~cm}$-esnek becsült hosszát, egy min. 227 cm hosszú tárgy képe körvonalazódik. Mindkét ásató régész hangsúlyozta azonban, hogy a feltárás során nem egy egész csónak került elő, hanem annak csak egy részletét találták meg. ${ }^{53}$ A rétegsorban kissé ferdén elhelyezkedő tárgy magasabban fekvő, hiányzó felét a tell felsőbb rétegei már korábban elpusztították. Eredeti hossza az ásatók szerint akár a négy-öt métert is elérhette [bár több újságcikk szerényebben csak

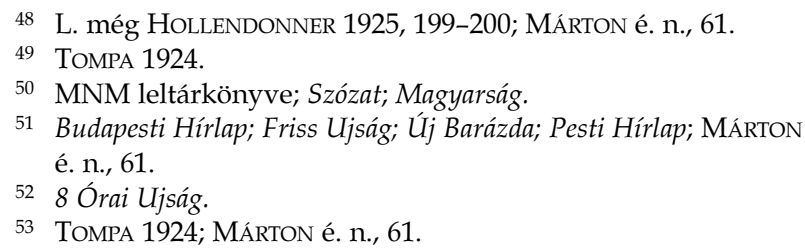

három méteres hosszúságot rekonstruált (pl. Szózat)].

Fennmaradt szöveges forrásaink a lelet további dimenziói tekintetében jórészt hasonló értékeket közölnek: legnagyobb szélessége $67 \mathrm{~cm}$, mélysége 35-40 cm volt. Oldalainak és aljának vastagságáról azon túl, hogy „vékony” volt, ${ }^{54}$ nincs információnk.

Az újságcikkek és egyéb leírások állításaival ellentétben az MNM Adattárában őrzött tárgyrajzok egy valamivel kisebb csónakról árulkodnak (5. kép). Az ezeken ábrázolt részlet („szabadon való rész") hosszúsága $145 \mathrm{~cm}$, legnagyobb szélessége $56 \mathrm{~cm}$. A Tompa Ferenc vázlatos felszínrajzait tartalmazó füzet utolsó lapján, a minden bizonnyal a csónakkal azonosítható objektum rajza mellett, ezzel szemben, szintén egy 180 cm-es hosszúságadat olvasható (11. kép 2).

\section{Anyag}

Anyagát illetően sem a korai újságcikkek, sem Márton Lajos kézirata nem szolgál támpontokkal. Az ásatást követően a tárgyból vett mintákat Hollendonner Ferenc kapta meg, aki az „igen korhadt, sárgás, szürkés barna" anyagból metszeteket készített. Makroszkopikus és mikroszkopikus megfigyelései szerint a minták egy lombos fa, leginkább a salix (füzfa) szövettani jellegzetességeit mutatták. ${ }^{55}$ A csónakhoz felhasznált füzfa, a lelet ismert legnagyobb szélességadataiból $(56 / 67 \mathrm{~cm})$ kiindulva és a fafaj mai példányain végzett összehasonlító kutatások adatait alapul véve, ${ }^{56}$ kivágásakor min. 46-55 éves lehetett.

\section{Készitéstechnika}

Bár a tárgy előállítási módja és technikai részletei kapcsán forrásaink elég szúkszavúak, abban jórészt minden kútfő egyetért, hogy emberi kéz alkotta. A feltáró régészek meggyőződése szerint a tárgy egykor csónaknak készült és annak megfelelően is használták, ezt alátámasztandó azonban csak kevés megfigyelést közöltek. Hollendonner Ferenc a lelet makroszkopikus vizsgálatát követően felvetette, hogy "ha egyéb okok - így a benne levő tárgyak - nem lettek volna, ezt is csak egy kidőlt odvas fúzfának kellene tartanunk" ${ }^{57}$ A beszámolókban a fatörzs megmunkálására egyetlen megállapítást találunk: Márton Lajos

54 MÁrton é. n., 60.

55 A megfigyelések részletes leírása: HOLLENDONNER 1925, 199_ 201; továbbá Budapesti Hírlap 1925. március 24.

56 RADÓ 1999, 12

57 HOLlendonNer 1925, 201. 


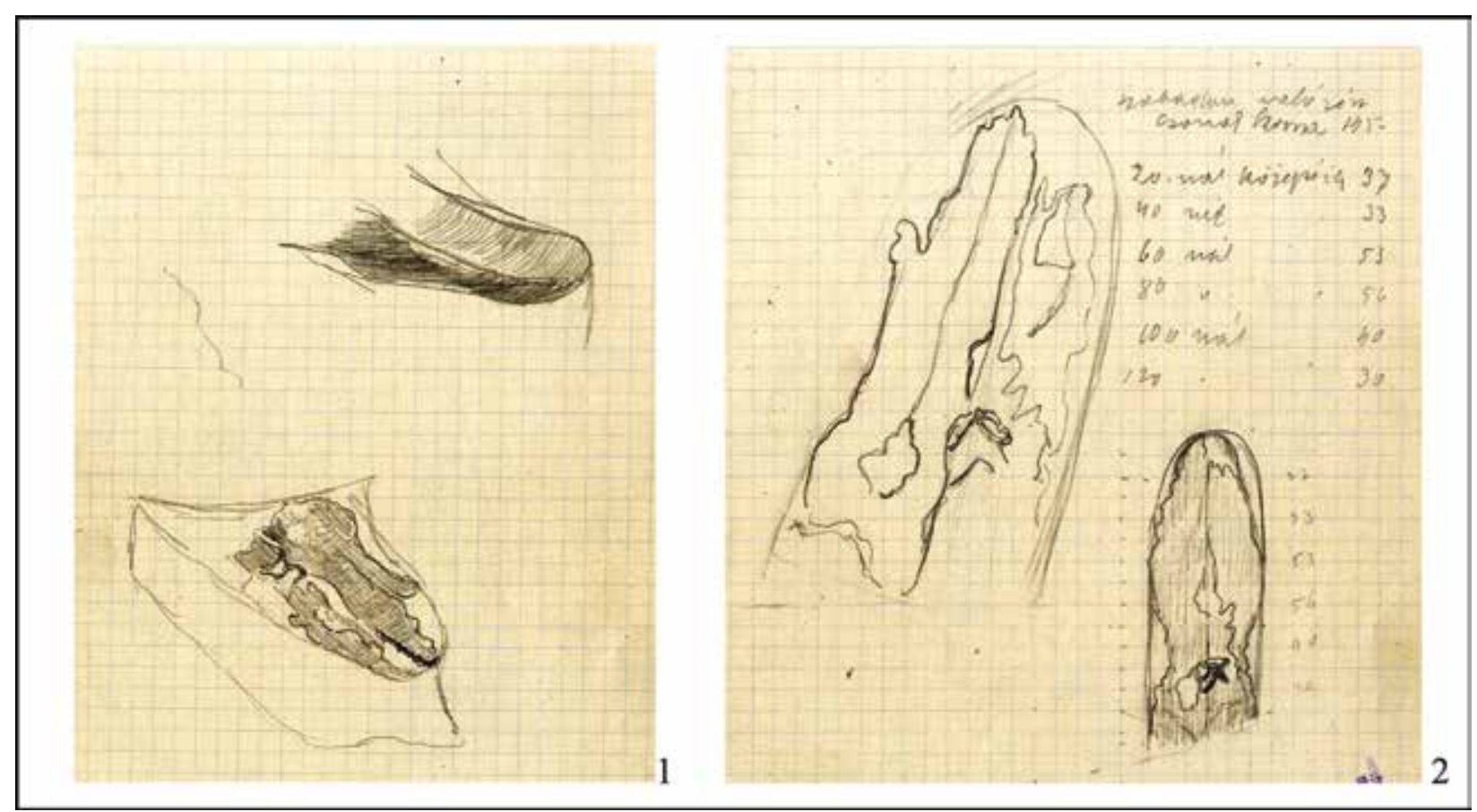

5. kép 1-2. A csónakról készült ceruzarajzok (MNM RA Tószeg T/I.a. 8. füzet)

Fig. 5. 1-2. Pencil drawings of the boat (MNM RA Tószeg T/I.a. 8. booklet)

szerint a múzeumba került tárgy megtisztításakor világosan kivehetô volt annak faragott pereme. ${ }^{58}$

Az újságcikkek többsége az ásatóktól kapott információkra hivatkozva a leletet kéregcsónakként írta le, egy-két esetben merült fel csupán más lehetóség. ${ }^{59}$ Tompa Ferenc feltehetően ezt a tévedést (is) megcáfolandó vetette papírra a Nemzeti Ujságban megjelent cikkét, ahol a készítés technikája kapcsán egyértelmúen vájt csónakról írt. ${ }^{60}$ Ezt a megfigyelést később Hollendonner is megerősítette: a tárgyat egyetlen fának az "odvas" törzséból vájták ki, ${ }^{61}$ amelyen az előadásáról tudósító egyik újságcikk szerint ${ }^{62}$ - a tanulmányában erről nem tesz említést - kéreg egyáltalán nem is volt.

A belső rész kialakításának, kivájásának részleteiról forrásaink nem adnak felvilágosítást. Noha Tompa részletesen ír cikkében a számos történeti és néprajzi korú bödönhajó esetén is jól ismert kiégetéses módszerról, ${ }^{63}$ a tószegi lelet kapcsán erre utaló megfigyeléseit nem dokumentálta. Hasonlóképpen ma már nem ellenőriz-

\footnotetext{
58 Márton é. n., 62.

59 L. a Pesti Napló cikkeit, amelyekben a tárgy anyagát farostként határozták meg.

60 TOMPA 1924.

61 HollendonNer 1925, 200.

62 Budapesti Hírlap 1925. március 24.

63 TOMPA 1924; MCGRaIL 1987, 62.
}

hető az a feltevése sem, hogy már a Tószegen élő „kőkori halász is bekente valamivel a csónakját, hogy annak tartósságát biztositsa" ${ }^{64}$

A leletról készült rajzokon jól látható, hogy a tárgy testét középütt több helyen különböző méretú, szabálytalan alakú lyukak, szakadások tagolják (5. kép 2). Formájuk alapján ezek lehettek a tárgy túlzott igénybevételéből eredő sérülések, esetleg természetes korhadás következményei, de a szándékos átfúrás lehetősége sem kizárt. Elképzelhető, hogy a rajzon látható „sérülések” olyan, eredetileg a kifaragást segító, vastagságmérő lyukakból (ún. gauge-holes) fejlődtek ki, amilyeneket őskori bödönhajók esetében gyakran megfigyeltek. ${ }^{65}$

\section{Forma}

A tárgy formáját a rendelkezésre álló leírások és rajzok alapján nem tudjuk pontosan rekonstruálni. A beszámolókban említett morfológiai vonások [pl. „lapos, kimélyített, keskeny, lekerekített” test, ${ }^{66}$ amely "a középfelé egy kissé lejt" (Szózat); „jellemző orr" (Szózat)] konkrétabb formai típusba sorolását nem teszik lehetővé. A lelet alakja a rajzokon és fényképeken (4-5. kép) némileg félre-

\footnotetext{
64 TOMPA 1924.

65 McGrail 1987, 61-62; GASPARI 2017, 105-108.

66 Márton é. n., 60.
} 
vezető: ott látható elkeskenyedő, lekerekített vége nem a csónak valódi vége (orra vagy tatja) volt, hanem az 1924. tavaszi áradás után hátramaradt töredékének a szelvényfalból kiálló, déli sarka (rekonstruált tájolását 1. alább). A megmaradt darab ábrázolásain belső bordáknak, osztófalaknak, egyéb szerkezeti elemeknek nincs nyoma.

A rajzok csak egy nézetből, felülről ábrázolják a leletet, így hossz- és keresztmetszeti alakjáról nincsen képi információnk. Keresztmetszeti formájára vonatkozóan elsősorban a közölt méretadatokból kiindulva nyerhetünk némi támpontot. Feltéve, hogy a tárgyat az alapanyagául szolgáló fatörzs külső részeinek jelentős lefaragása nélkül alakították ki, szabályos körszelet vagy lapított ellipszisszelet alakú átmetszettel számolhatunk - noha utóbbi lehetőség valószínúbb a kivágást követő természetes száradás során történő alakváltozás ${ }^{67}$ és a tell felsőbb rétegeinek nagy súlya okozta deformáció miatt. Szabályos körszelet keresztmetszet esetén a csónak testére az ismert metrikus paraméretek (legnagyobb szélesség 56-67 cm, mélység 35-40 cm) alapján minden esetben igaz az az összefüggés, hogy mélysége nagyobb volt, mint a felhasznált fatörzs sugara, amiből következik, hogy legnagyobb szélességét nem a pereménél, hanem még az alatt érte el, azaz pereme már befelé fordult. Ha a tárgy keresztmetszetéhez egy lapított ellipszisszelet formát feltételezünk (ahogy azt a Szózat cikke is sejteti: „a felette lerakodott rétegek lenyomták, deformálták, ellapították"), akkor az ismert méretadatok szerint pereme még inkább visszafelé hajlott. Mindkét rekonstrukció (6. kép) arra utal, hogy a csónak kialakításához nem egy félfát, hanem egy teljes fatörzset használtak fel. Természetesen, ha a tárgy keresztmetszete nem a fatörzs eredeti kontúrját követte, hanem azt szándékos lefaragással kívülról is átalakították, a metrikus adatok alapján tett megállapítások nem érvényesek, átmetszeti formájára vonatkozóan csak találgathatunk.

A lelet alakját illetően további útmutatásként szolgálhat Tompa Ferenc Nemzeti Ujságban megjelent írása, amelyben ismeretterjesztő céllal ugyan, de a felfedezés jelentőségét hangsúlyozandó számos őskori és bronzkori bödönhajót sorol fel Európa különböző részeiről. Bár ezen csónakok többsége valószínúleg csak funkciójukat nézve tekinthetó a tószegi tárgy párhuzamának, egy a skóciai Loch Canmorban (Loch Kinord/Kinnord) talált csónakot a szerző külön is kiemelt, lévén az „formájára és állapotára

67 McGrail 1987, 41-43.

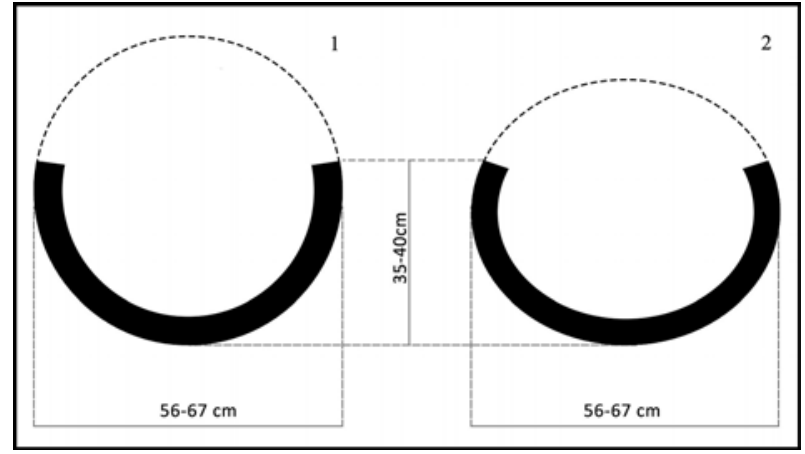

6. kép. A bödönhajó rekonstruált keresztmetszete: 1 . kerek átmetszet esetén; 2 . ovális átmetszet esetén

Fig. 6. Reconstructed transverse section of the logboat: 1 . in case of round cross-section; 2 . in case of oval cross-section

nézve a legjobban hasonlit a mi leletünkhöz, sőt bátran mondhatjuk, hogy annak szakasztott mása". ${ }^{68}$ A feltételezett párhuzam kapcsán Tompa nem bocsátkozott részletes leírásba, közzétett viszont egy rajzot „A Loch canmori csónak..." felirattal. A kép (feltehetően) első közlése a Proceedings of the Society of Antiquaries of Scotland 6. kötetéböl ismert, ${ }^{69}$ ahonnan később Robert M. A. Munro is átemelte skóciai cölöpépítményekről szóló könyvébe $^{70}$ (7. kép) - Tompa vélhetóen ez utóbbit használta forrásként.

Mai tudásunk szerint a Canmor-tóból Tompa idejében három bödönhajó volt ismert. ${ }^{71}$ Stuart és Munro idézett forrásai és megjegyzései alapján a Tompa által rajzzal is hivatkozott darab ezek közül bizonyosan a leghíresebb, „királyi jachtnak" is nevezett csónakkal azonosítható. ${ }^{72}$

A Loch Canmor-i "királyi jachtot” 1859-ben a tó északi partjának közelében hozták felszínre. Noha kiemelését követően tönkrement (ma már csak egy töredéke ismert), egykori morfológiai jegyei és méretei rekonstruálhatók (7. kép). A beszámolók a tószegi darabhoz képest egy szélesebb $(1 \mathrm{~m})$ és hosszabb $(6,9 \mathrm{~m})$ csónakról írnak, amelyet egyetlen tölgyfa törzséből faragtak ki, oly módon, hogy tatjánál szögletes keresztmetszetú lett, orránál pedig elkeskenyedett. Mélysége a leírás szerint nem egyenletes, de összességében a tószegihez képest jóval sekélyebb (max. $22,5 \mathrm{~cm}$ ) lehetett. Szélei elvékonyodtak, aljának vastagsága

68 TOMPA 1924.

69 SMITH 1866, 258; minden bizonnyal STUART 1866-hoz tartozó illusztáció.

70 Munro 1882, XV, 23, Fig. 1.

71 Ez a szám azóta négyre emelkedett: 1. https://canmore.org. uk/site/84532/loch-kinord.

72 StuART 1866, 150, 170-171; Munro 1882, 22-23. A tárgy részletes leírását 1. még: https://canmore.org.uk/site/84532/ loch-kinord; ábrázolását 1. MunRo 1882, 23, Fig. 1. 


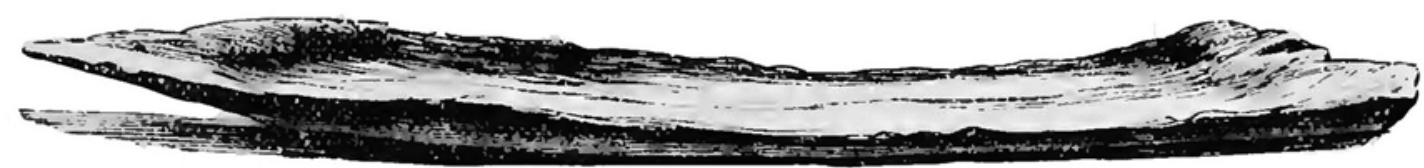

7. kép. A Loch Canmor-i csónak rajza (MunRo 1882, XV, 23, Fig. 1)

Fig. 7. Drawing of the Loch Canmor logboat (MunRo 1882, XV, 23, Fig. 1)

kb. $10 \mathrm{~cm}$ volt. Alján szabálytalan távolságokra, párokba rendeződve $5 \times 2 \mathrm{db}$ kerek, kb. $4,5 \mathrm{~cm}$ átmérőjú átfúrás (vastagságmérőlyuk) látszott. Testén javítás nyomait is megfigyelték: a csónaktesten kialakult hosszanti repedéseket úgy igyekezték orvosolni, hogy a fatörzsbe kívülről két hosszanti és több keresztirányú tölgyfalécet sülylyesztettek és egymáshoz csapolták őket.

Mivel az összehasonlítás alapjául szolgáló kritériumokat Tompa nem tartotta fontosnak részletezni, nem világos, hogy a fent leírt csónak mely vonásaiban lehetett a tószegi tárgy „,szakasztott mása". A párhuzam kisebb szépséghibája, hogy a „királyi jacht” megmaradt darabján végzett radikarbon mérés újabban a csónak kora középkori voltát (6-7. század) mutatta ki. ${ }^{73} \mathrm{Ez}$ azonban nem zárja ki annak lehetőségét, hogy a két lelet formai és készítéstechnikai szempontból ténylegesen hasonlított egymásra, mivel több bödönhajókkal foglalkozó összehasonlító kutatás is bizonyította, hogy a technika alkalmazása térben és időben széles skálán mozog, az egyes formai típusok morfológiai jegyei alapján univerzális tipokronológiai szabályszerúségek nem mutathatók ki. ${ }^{74}$

\section{Régészeti kontextus}

\section{Stratigráfiai viszonyok}

A csónak stratigráfiai helyzetét illetően a szakirodalomban több pontatlansággal is találkozunk, amelyek minden bizonnyal a lelettel kapcsolatos forrásanyag hiányos ismeretén alapulnak. Az elsó és máig meghatározó publikáció, amely a lelet kontextusára vonatkozóan részleteket közölt, Banner Jánosnak Márton Lajos kéziratát, illetve az annak mellékletét képező összesítő felszínrajzokat is közreadó munkája. ${ }^{75} \mathrm{~A}$ cikk

\footnotetext{
73 Stratigos 2015.

74 ARNOLD 1996, 32-37; LANTING 2000, 627, 644-645.

75 BANNER-BÓNA-MÁRTON 1959.
}

Márton nyomán a csónakot a 4. települési szint (4. Horizontalprofil) leírása során említi és az adott szint felszínrajzán, az 1927-es ásatás északi szelvényében tünteti fel ${ }^{76}$ (8. kép). A rendelkezésre álló korabeli források újbóli áttekintése során mindkét állítás tévesnek bizonyult.

A félreértések forrása Márton Lajos monográfiájának eredeti kézirata, amely - annak minden ismert változatában - a csónak előkerülésének történetét a 4 . települési szint régészeti jelenségeinek leírása közé ékelve ismerteti. ${ }^{77} \mathrm{~A} 4$. szintet leíró fejezet szövegének tartalmi elemzése azt sugallja, hogy a csónakkal foglalkozó részlet (15 mondat) csak igen laza szállal kapcsolódik szövegkörnyezetéhez, sokkal inkább egy önálló egységnek tûnik, amelyet a szerző valamilyen oknál fogva utólag illesztett be a mú ezen traktusába. Annak fényében, hogy Márton az 1924-es ásatás megfigyeléseiról kéziratában alig tett emítést, összesító felszínrajzain pedig többször a Tompaféle 1924. évi felszínrajzoknak ellentmondó adatok jelennek meg, elképzelhető, hogy monográfiája írásakor ezen év eredményei nem, vagy csak hiányosan álltak a rendelkezésére, így a csónak bemutatását is emlékezetből vetette papírra. Hogy miért éppen a 4. szint jelenségei között számolt be róla, csak találgatni tudjuk (a hiba talán a szintek évenként eltéró irányú számozására vezethetó vissza).

A lelet horizontális helyzetének téves azonosítása ${ }^{78}$ valószínúleg szintén azzal magyarázható, hogy Mártont memóriája idővel cserben hagyta. Amikor a csónakról szóló szövegrészletet lezárta és beillesztette a 4. szint két, az 1927-es ásatás idején feltárt objektumának ${ }^{79}$ rövid leírása mögé,

76 BANNER-BÓNA-MÁRTON 1959, 40, 56, Abb.25 (l. Cs); BÓNA 1975,164

77 MÁrTon é. n., 60-62.

78 Téves helyzetét 1 . már a 4. szint eredeti összesítő felszínrajzán: MNM RA Tószeg 1-2. T.I.a. ltsz.: 4149.

$79 \mathrm{P}_{3-4}$ házmaradvány, ehhez 1 . BANNER-BÓNA-MÁRTON 1959, 40, 56, Abb.25; HeYworth 1984, 31, Sheet D. 


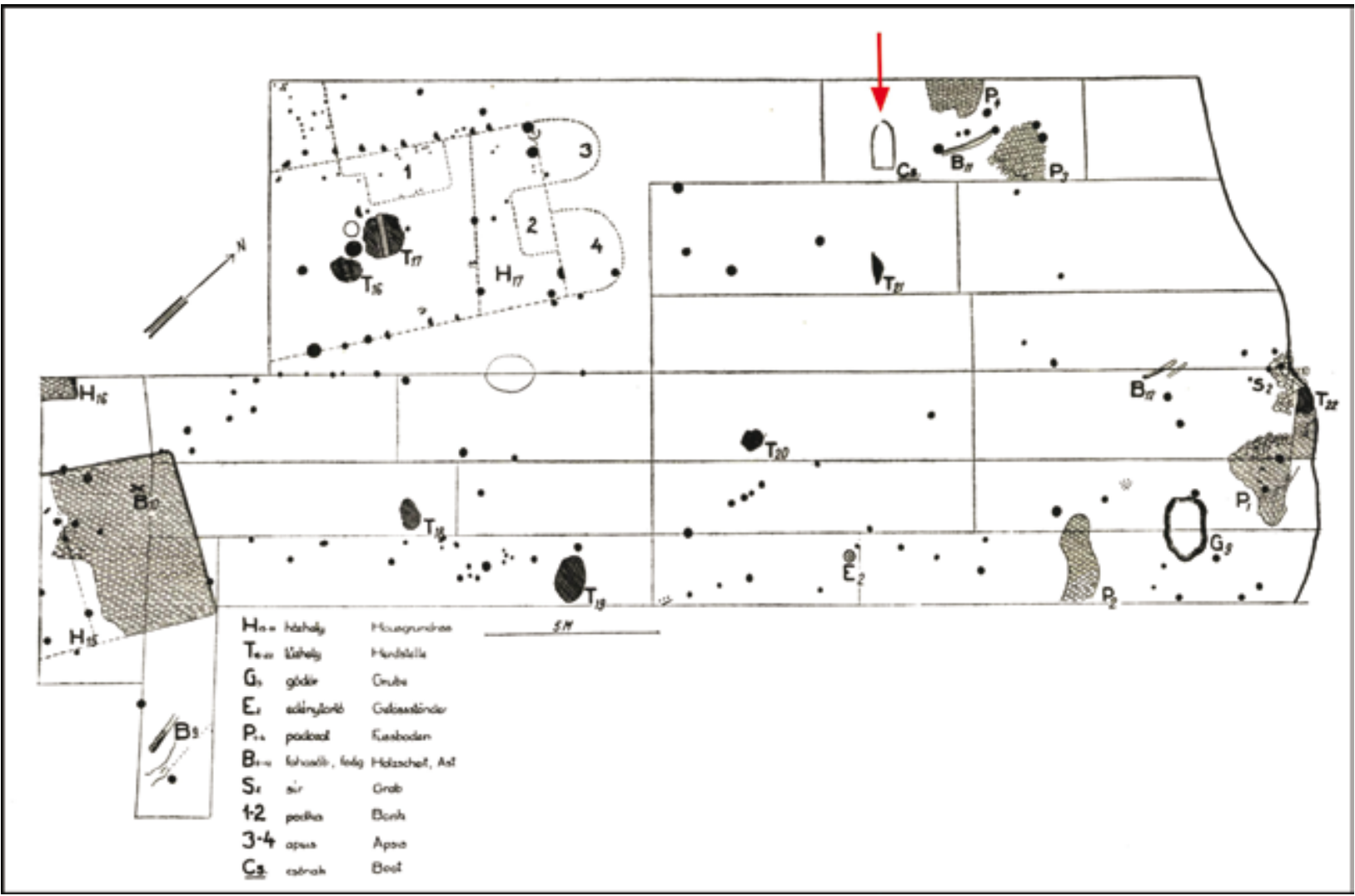

8. kép. Márton Lajos összesítő felszínrajza (Horizontalprofil) a 4. települési szintről (BANNER-BÓNA-MÁRTON 1959, 56, Abb. 25 nyomán)

Fig. 8. Summary plan (Horizontalprofil) of the 4th level by Lajos Márton (after BANNER-BÓNA-MÁRTON 1959, 56, Abb. 25)

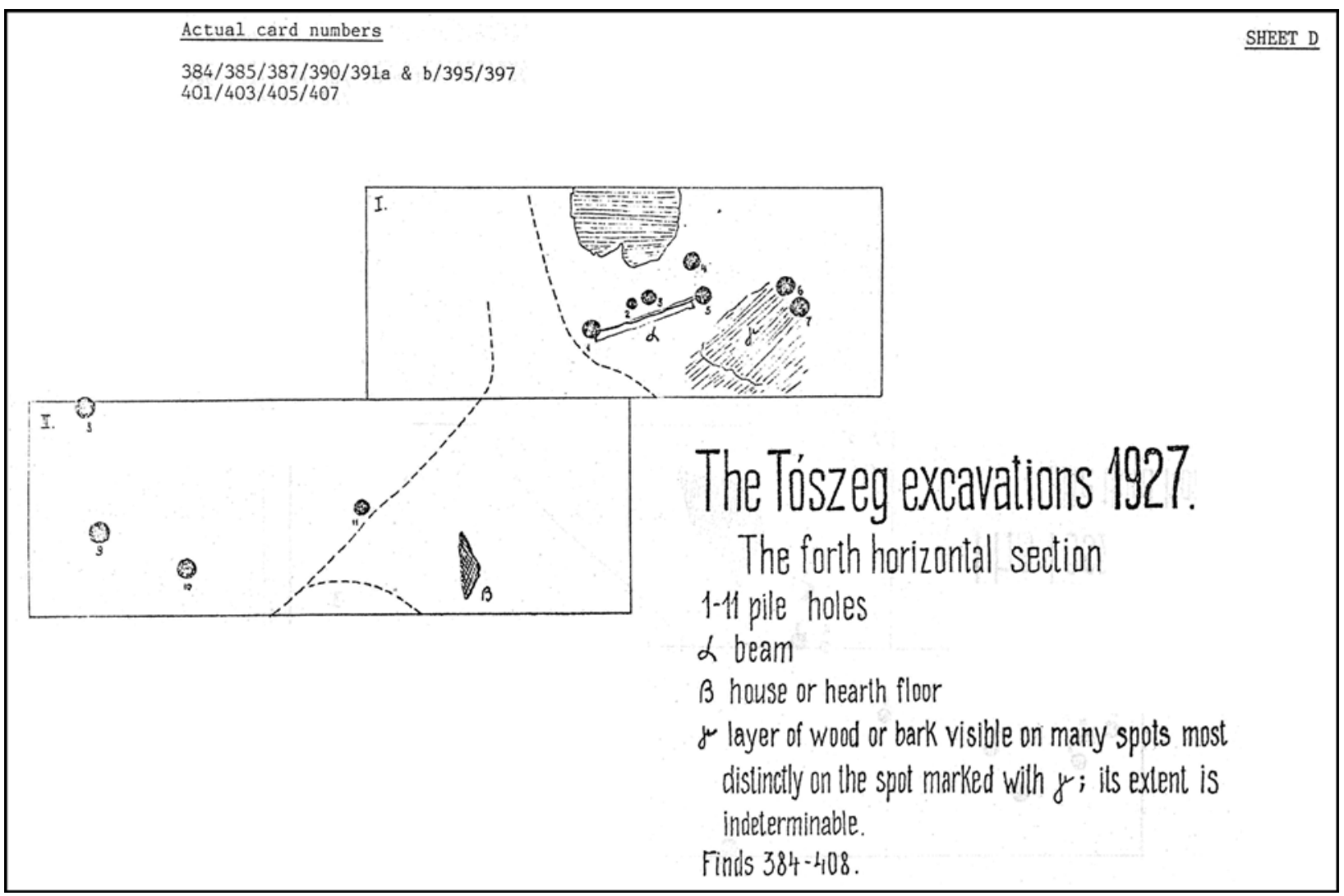

9. kép. Az 1927. évi feltárás 4. települési szintjének felszínrajza (HEYWORTH 1984, Sheet D)

Fig. 9. Plan of the 4th level (horizontal section) excavated in 1927 (HEYwORTH 1984, Sheet D) 


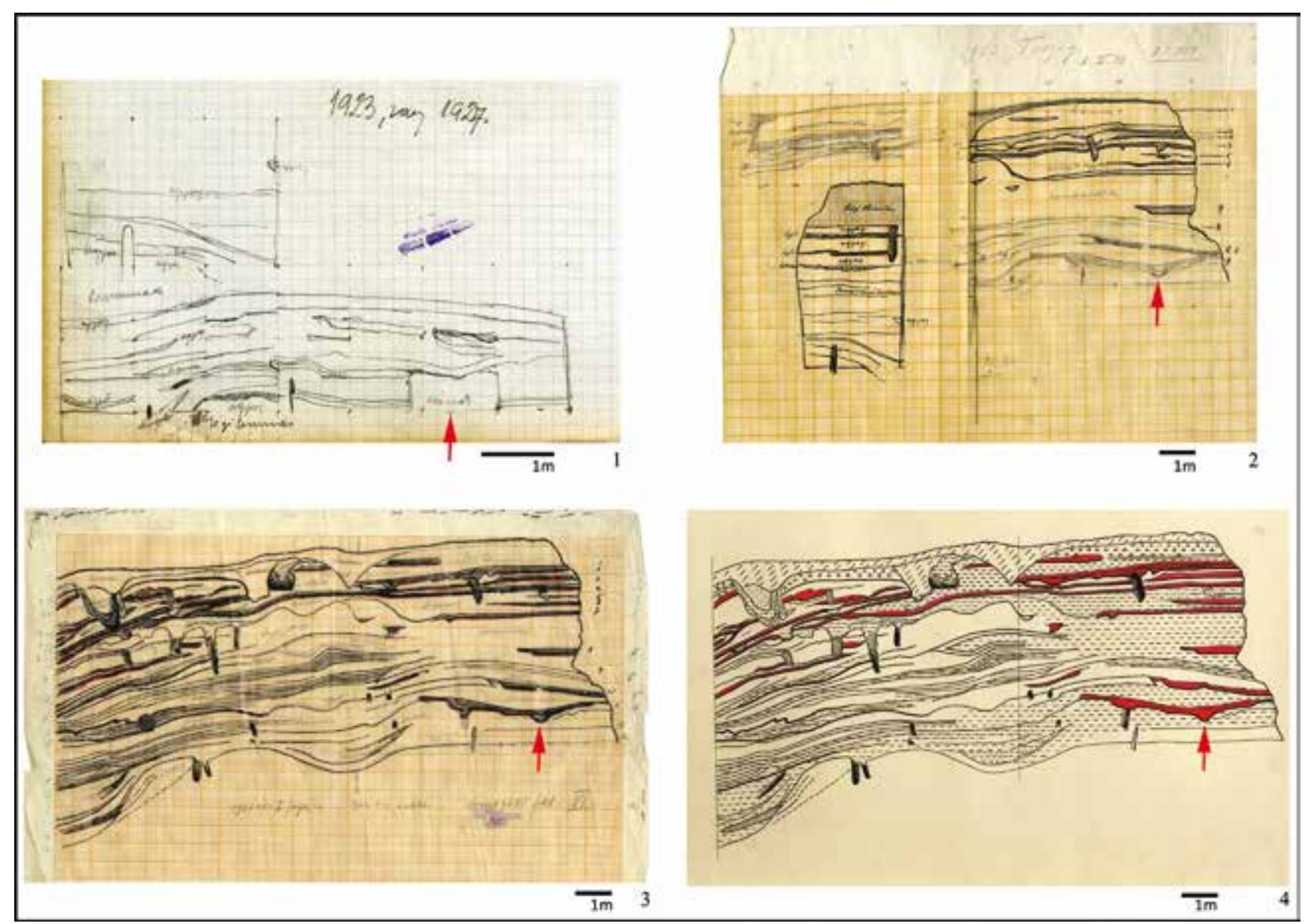

10. kép. Az 1923. évi szelvény északi metszetfalának rajzai (1-4. fázis) (MNM RA Tószeg T/I.a. 8. füzet; Tószeg 1-2. T.I.a. ltsz.: 4149)

Fig. 10. Drawings of the northern porfile of the section excavated in 1923 (1st-4th phases) (MNM RA Tószeg T/I.a. 8. booklet; Tószeg 1-2. T.I.a. inv. nr.: 4149)

még tisztában volt vele, hogy azok nem egy időben és nem egy szelvényben kerültek elö, ${ }^{80} \mathrm{az}$ összesítő felszínrajzok összeállításakor azonban már együtt, ugyanazon a felszínen, méghozzá az 1927. évi feltárás északi szelvényében ábrázolta őket. A tévedést világosan alátámasztják az 1927es ásatásnak az MNM és a CUMAA archívumaiban őrzött felszínrajzai, amelyeken a csónaknak nyoma sincs ${ }^{81}$ (9. kép).

A korábban ismeretett források (ásatási dokumentációk és sajtóhírek) tükrében egyértelmú, hogy a lelet az 1923-as és az 1924-es feltárás szelvényeinek határán, egy olyan térségben került elő, amely noha a feltárás idején már a tell erósen omladékos, keleti szélén terült el, annak legna-

80 A csónak leírása a $P_{3-4}$ házmaradvány ismertetését követóen az alábbi mondattal kezdődik: „Beim Ausgraben der daneben liegenden Fläche..." (Márton é. n., 60).

81 MNM RA Tószeg T/I.a. 18. mappa; HeYworth 1984, 28-67, Sheet A-P. Bár a 4. szint eredeti felszínrajza az MNM-ben hiányzik, annak a CUMAA archívumában található másolata igazolja a tévedést. gyobb kiterjedést mutató, középső bronzkori fázisában még valószínúleg a település központi zónájában lokalizálható. ${ }^{82}$ A tárgy 1923-ban talált darabjának helyzetét csak metszetrajzról ismerjük (10. kép), az 1924-es szelvénybe eső nagyobb felét felszínrajzon és fotókkal egyaránt dokumentálták (11. kép 2; 4. kép). Utóbbiak alapján tájolása ÉÉNy-DDK-i irányú lehetett.

Rétegsoron belül elfoglalt vertikális pozícióját tekintve forrásaink egyöntetúen cáfolják a 4 . szinthez kötését, a csónakot a halom alsóbb rétegeivel, a település használatának korábbi időszakával hozzák kapcsolatba. A sajtóban megjelent híradások több közvetlen és közvetett stratigráfiai adatot is szolgáltatnak. Tompa Ferenc a Nemzeti Ujságban arról írt, hogy a leletet a „hét egymás fölött lévő kulturréteg” közül a „legalsó, fiatalabb kőkori rétegben" találták meg, ${ }^{83}$ míg a Pesti Hírlap szerint a "legalsó kulturréteg alatt, négy

82 BANNER-BÓNA-MÁRTON 1959, 32, Abb. 5.

83 TOMPA 1924. 


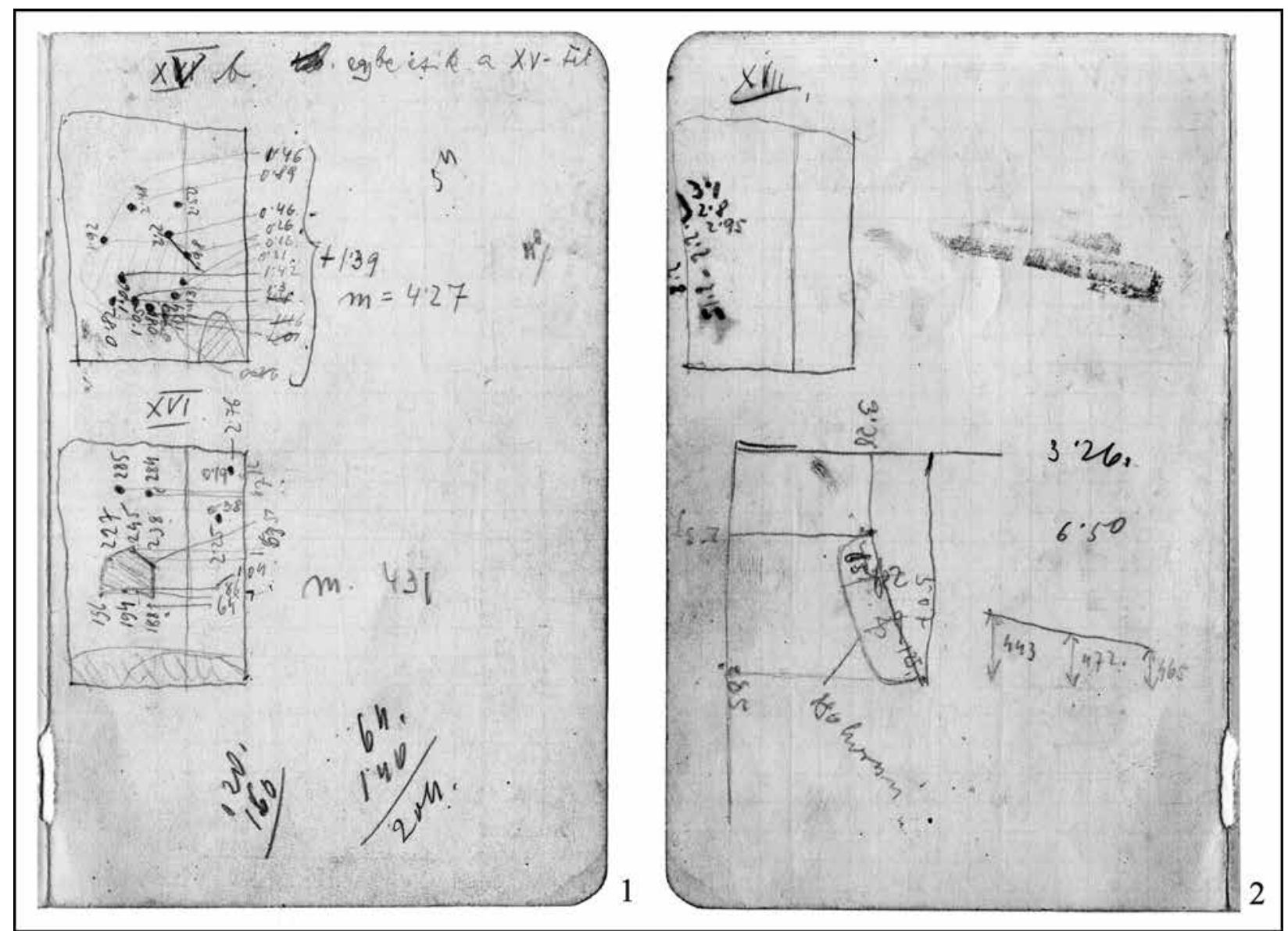

11. kép. Az 1924. évi ásatás felszínrajzai (Tompa Ferenc vázlatai): 1. XVb-XVI. szintek; 2. A csónak elhelyezkedése (MNM RA Tószeg T/I.a. Tompa feljegyzései 1924 Tószeg)

Fig. 11. Plans of the section excavated in 1924 (sketches from Ferenc Tompa): 1. XVb-XVI. levels; 2. Location of the boat (MNM RA Tószeg T/I.a. Tompa feljegyzései 1924 Tószeg)

méternyi mélységben" bukkant fel. Az újságcikkek többsége emellett számos, a lelet korára vonatkozó utalást is tartalmaz (, a fiatalabb kőkorszak végéről” [8 Órai Ujság], „a Krisztus előtti harmadik évezredből való" [Szózat]), amelyek a korabeli tudományos elképzelések tükrében, miszerint az első közösségek a tószegi tellen a neolitikum fiatalabb idószakától kezdve települtek meg $^{84}$ (szemben a mai kora bronzkori állásponttal), közvetve szintén a csónak korai rétegekhez kötését valószínúsítik. (A 3. évezredbeli datálás, bár mai tudásunk fényében meglepően pontosnak túnik, véletlen egybeesés, és az újkőkor abszolút időrendi kereteivel kapcsolatos korabeli nézeteket tükrözi. ${ }^{85}$ )

Az újságikkek állításait támasztják alá az 1924es feltárás során készített fotók (amelyek egyikét a Magyarság átrajzolva közölte is) (4. kép 1) ${ }^{86}$ és az 1923-as szelvény északi metszetfaláról készült

\footnotetext{
84 TOMPA 1924.

85 CHILDE 1929, 414-415.

86 Vö. BóNA 1980, 88, 8. kép.
}

rajzok is (10. kép). Ezeken a lelet egyértelmúen a hozzávetőleg öt méter vastagságú rétegsor alján, a „mélyre ásott domb egyik zugában” (Magyarság) túnik fel, pontos rétegtani egységhez, illetőleg települési szinthez kötése ugyanakkor az egymásnak ellentmondó adatok miatt bizonytalan. Az 1923-as szelvény északi falának stratigráfiája több metszetrajzon is fennmaradt, amelyek a rétegsor dokumentálásának és feldolgozásának négy egymást követő állomását képviselik (10. kép). Míg a csónak a kizárólag az 1923-as megfigyeléseket rögzítő 1 . és 2 . fázisban még többé-kevésbé felismerhető, az 1927-es (déli) szelvény stratigráfiájával is kiegészített 3. és 4 . fázisban ${ }^{87}$ már beleolvad a felette lévő réteg jelenségeibe. A 2. és 3. fázis rajzain az ásatók felülről lefelé beszámozták az 1923-as ásatás során feltárt rétegeket: ez alapján a tárgy közvetlenül a 9. (1. 2. fázis), illetve a 11. (1. 3. fázis) települési szint alatt, a metszetek méretarányából kiindulva 4,75-4,9 m

87 Utóbbit 1. BANNER-BÓNA-MÁrTon 1959, Abb. 17, Profil 31. 


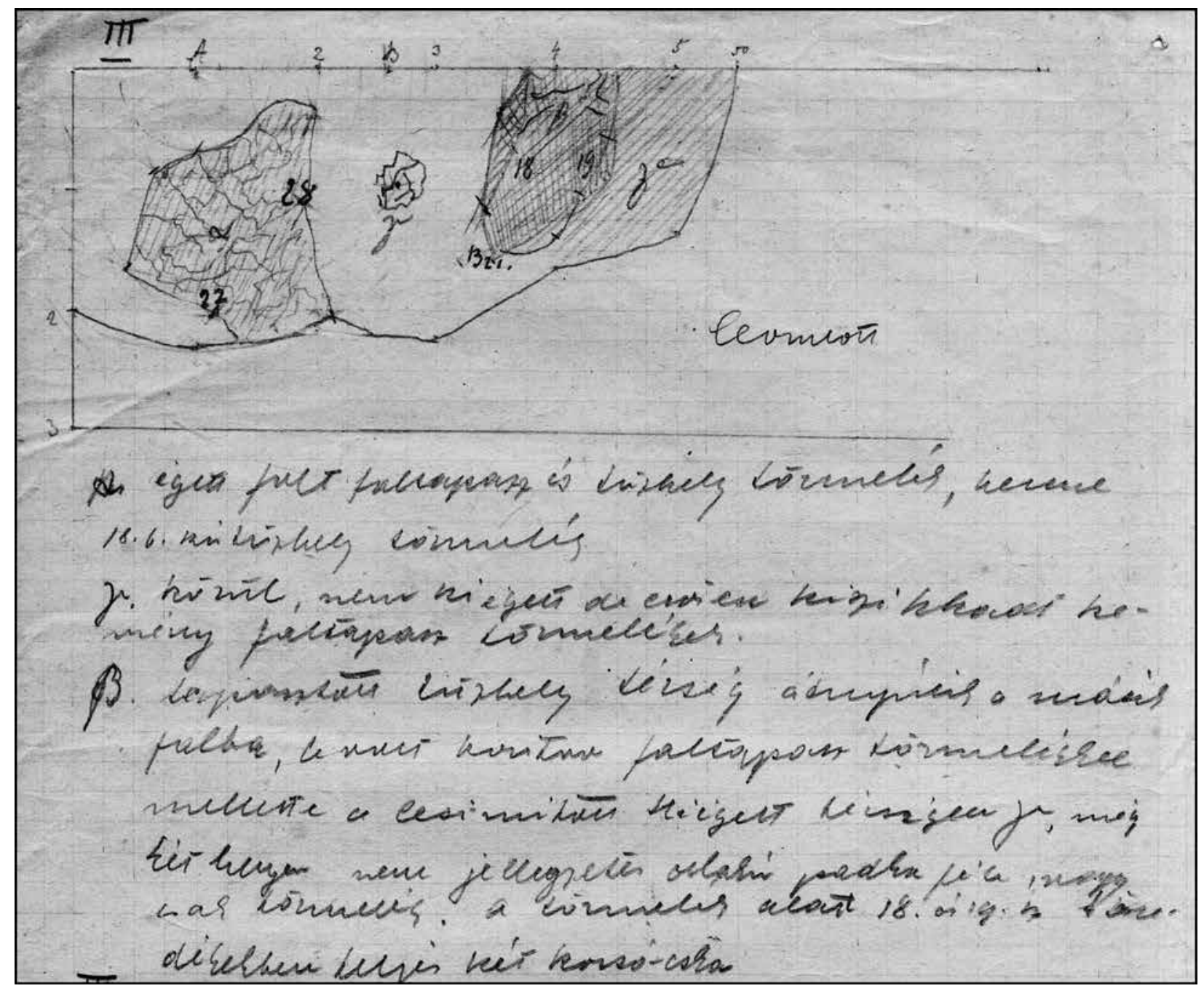

12. kép. Az 1923. évi ásatás III. színtjének felszínrajza (MNM RA Tószeg T/I.a. 18. mappa)

Fig. 12. Plan of the 3rd level (horizontal section) excavated in 1923 (MNM RA Tószeg T/I.a. 18th folder)

mélységben került elő. A két metszetrajzon megfigyelt eltéró rétegszámozás háttere nem teljesen világos: úgy túnik a kezdeti 10 szintet később újragondolták és 13-ra bóvítették. A csónakot a metszetrajzok alapján vele kapcsolatba hozható egyik települési szint (az alulról felfelé számozott III. [12. kép] és IV. szint) 1923. évi felszínrajzán sem ábrázolták. 88

A tárgy pontos stratigráfiai helyzetének tisztázását bonyolítja az 1924-es feltárás fennmaradt dokumentációja, amely már 16 települési szint szétválasztásáról árulkodik, de hogy ez a stratigráfia hogyan viszonyul az újságok által említett hét „kultúrréteghez” és az előző évi feltárás 10/13 szintjéhez, az nehezen érthető. ${ }^{89}$

\footnotetext{
88 Az eredeti felszínrajzok: MNM RA Tószeg T/I.a. 18. mappa.

89 Vö. a 3. képet, amelyről az 1924-es feltárás stratigráfiája hiányzik.
}

Az 1924-es ásatás viszonylatában a csónak rétegtani helyzetét illetően két támpontunk van. Bár a lelet a Tompa Ferenc fentebb említett kis füzetében szereplő 16 számozott felszínrajz közül egyiken sem azonosítható, a füzet utolsó lapján papírra vetett számozatlan szintvázlaton gyaníthatóan mégis ennek a rajza látható (11. kép 2). A füzetlapon olvasható, települési szintre utaló adat (XIII.) helyzete és írásmódja alapján nem a csónak rajzához tartozik. Vertikális pozíciója kapcsán további fogódzót nyújthat a rajz mellé írt néhány szám (sorban 443, 472, 465), amelyek talán mélységadatként értelmezhetők és a csónak egyes részeinek felszíntól mért távolságát jelölhetik. Ezt a feltételezést erősítik az ásatáson készült fényképek és az 1923-as metszetrajzok adatai is, ellene szól ugyanakkor összevetésük a Tompa füzetében az egyes szintek felszínrajzaihoz tartozó mélységekkel. Nehezen feloldható az 
az ellentmondás, hogy az 1924. évi ásatás legalsó, XVI. szintjét a füzet szerint 4,31 m mélyen dokumentálták (11. kép 1), ami majdnem egy méterrel az 1923-as szelvény alja, és fél méterrel a csónaknak az 1923. évi metszetfalon ábrázolt pozíciója $(-4,75-4,9$ m) felett található.

A lelet régészeti kontextusáról forrásaink néhány közelebbi adattal is szolgálnak. Több újságcikk arról ír, hogy a tárgy, ",amint azt a felette és körülötte talált kulturmaradványok bizonyítják" (8 Órai Ujság) - bármit is értsenek pontosan alatta -, egy "kulturrétegben” feküdt (Budapesti Hírlap, Friss Ujság, Új Barázda stb.), míg másutt némileg eltéró kép rajzolódik ki környezetéről (Szózat, Nemzeti Ujság, Pesti Hírlap). A két feltáró közül Márton Lajos úgy emlékszik vissza a csónakot rejtő földtömeg kiemelésére, mint egy meglehetősen nehéz feladatra, amelyet hátráltatott, hogy "die Erde mit Scherben, Knochen etc. voll und eine lockere Kulturschichte war". ${ }^{90}$ Tompa Ferenc, ezzel szemben, a Nemzeti Ujságban megjelent cikkében és más orgánumok számára adott interjúiban következetesen azon megfigyelését hangoztatta, hogy a leletnek csak egy része, és az is csak közvetve (bolygatás révén) hozható kapcsolatba kultúrréteggel, elsődleges kontextusa egy árvízi hordalékréteg lehetett, amely „azt teljesen eltakarta a föléje települő őskori ember szeme elől". ${ }^{91}$ A Szózat és a Nemzeti Ujság leírása szerint „a csónak [...] rézsutason feküdt a földben", azaz egyik vége a rétegsorban magasabban helyezkedett el a másiknál. A fennmaradt fotók és leírások szerint ez a felálló rész a leletnek az északi vége kellett, hogy legyen, amely idővel, ahogy az iszapréteg felett „újabb település történt” (Pesti Hírlap) és amint "dereka már egy fölötte levő kulturréteggel érintkezett" (Nemzeti Ujság), elpusztult. Noha ezen leírások azt sugallják, hogy a csónakot eredetileg befogadó rétegtani környezet egy homogén, leleteket és objektumokat alig tartalmazó közeg lehetett, a korabeli ásatási és dokumentációs módszerek korlátainak ismeretében ezt fenntartással kell kezelni.

A beszámolók alapján a csónakkal egyetlen régészeti jelenség hozható összefüggésbe: egy a közvetlenül felette fekvő települési szinten/ kultúrrétegben feltárt „túzpad” (tüzhely) (Szózat), amelynek lényegében pusztulását is köszönhette. A túzpad azonosítására a csónak stratigráfiai pozíciójának ismeretében tehetünk kísérletet: az 1923. évi rétegsor 9./11. szintjének megfelelő III. felszínrajzon (12. kép), valamint az 1924. évi ásatás XVI. szintvázlatán (11. kép 1) is

\footnotetext{
90 MÁrton é. n., 62.

91 TOMPA 1924.
}

látható olyan objektum, amely túzhelyként interpretálható. Mivel a csónakot sem az 1923-as, sem az 1924-es feltárás szintadattal ellátott felszínrajzain nem ábrázolták, régészeti kontextusát illetően elértük forrásaink határát.

\section{Leletösszefüggések}

A csónak feltárásával egyidejúleg előkerült további leletekról kevés adatunk van. Az újságok híradásai között előfordul ugyan, hogy a csónak korát alátámasztandó, ${ }^{92}$ esetleg egykori használóiról képet alkotandó ${ }^{93}$ tárgyakat említenek vele összefüggésben, az esetek többségében azonban nem világos, hogy itt ténylegesen a csónakkal együtt előkerült tárgyakról, vagy csupán olyan leletekról van szó, amelyekre az 1923-as/1924-es ásatás során a tell valamelyik rétegében bukkantak.

Biztosan csak két lelet hozható a csónakkal szorosabb kapcsolatba. A Szózat újságírója, miután volt szerencséje még konzerválása előtt az MNM előterében megtekinteni a tárgyat, a következőket írta: „a fenekén egy szarvasagancsból készült kapa van, mellette egy csonttörmelék: fogsor." Bár az (emberi?/állati?) fogsorra vonatkozóan más forrásunk nincs, az agancskapát több kútfó, így Márton Lajos kézirata is említi. ${ }^{94}$ Utóbbi nyomán tudjuk, hogy az általa kalapácsnak vélt eszközt („Hirschgeweihhammer") már a kiemelés előtt, az ásatás során észlelték. A csónakról készült rajzok közül többön is jól kivehetó a tárgy formája és in situ pozíciója: a csónak belsejében, középtájon, közvetlenül a fentebb említett egyik nagy szakadás mellett feküdt, oly módon, mintha élével már a lyukba lógna (5. kép 2).

A csónakkal együtt talált leletekről az MNM leletárkönyve sajnos nem ad felvilágosítást. Az 1924. évi ásatás anyagából a csónakon kívül további 73 tárgy kapott leltári számot, ezek többsége ugyanakkor ma már nincs meg. Összesen hat tárgy (két kőbalta, négy agancs-, illetve csonttárgy) azonosítható a múzeum gyújteményében, amelyek biztosan az adott évi ásatáshoz köthetők, bár stratigráfiai helyzetük nem ismert. Ezek között a források által említett fogsornak és agancskapának nincs nyoma. Míg előbbire vo-

92 Pl. Pesti Hírlap: „a vele kapcsolatos földből, edényekről, szarvasaggancsból készült baltákról arra következtetünk, hogy evvel a lelettel a kulturhistória egyik legrégibb emléket ástuk ki".

93 Pl. Pesti Napló: „,a csónak mellett szigonyokat, halszerszámokat fedeztek fel, melyekből megállapították, hogy egy őshalászé voltak".

94 MÁrton é. n., 61. 

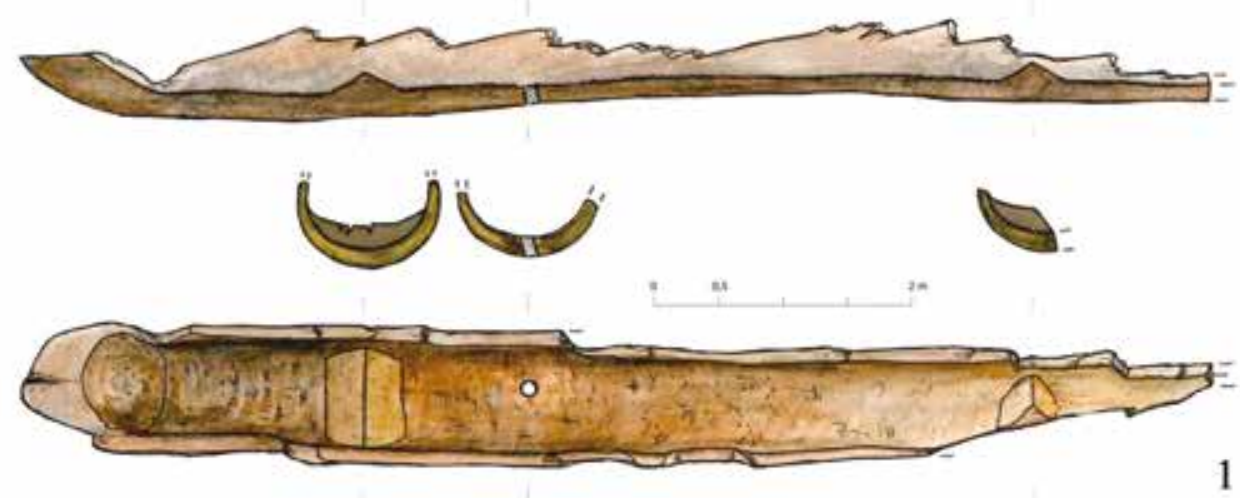

1
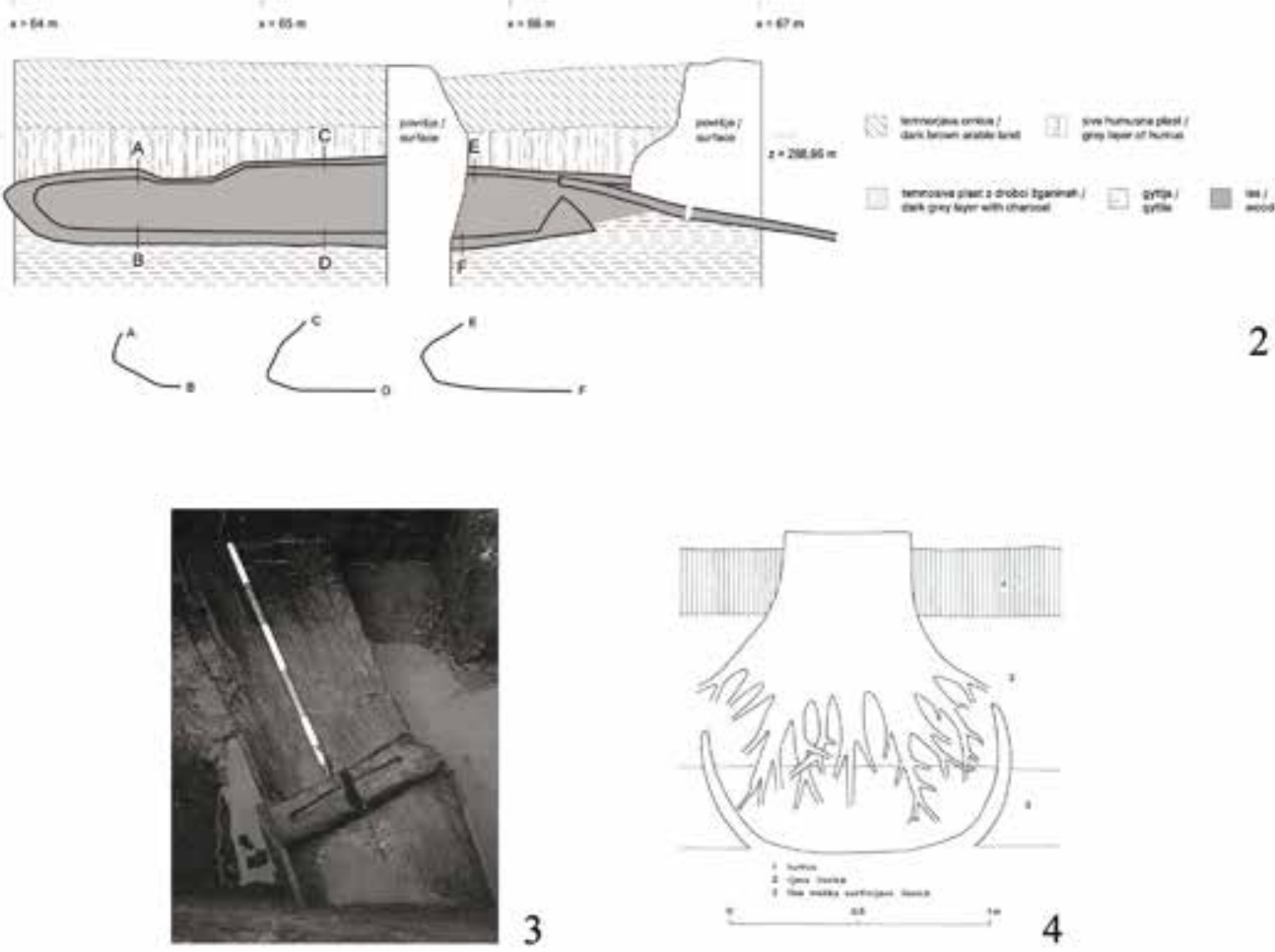

3

4

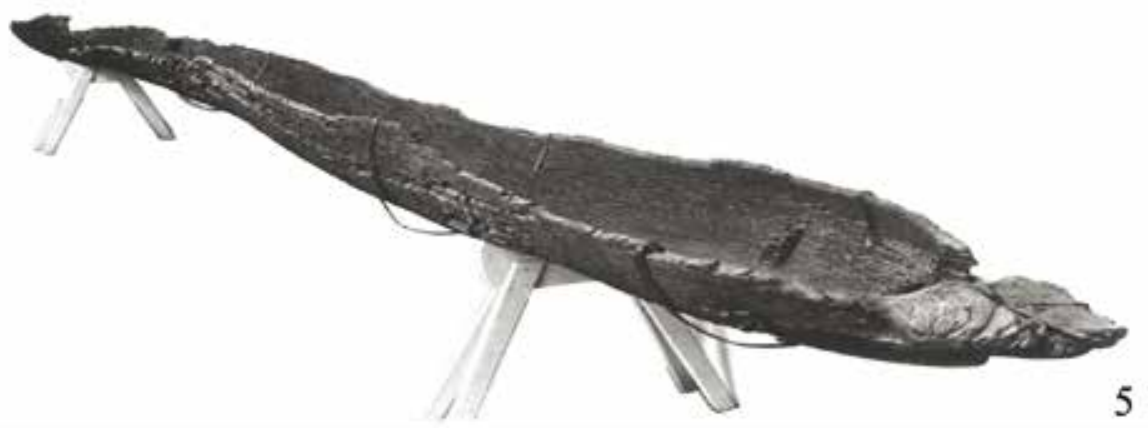

13. kép. Őskori bödönhajók a Kárpát-medencéből (Szlovénia): 1. Hotiza (h: 9,34 m, ERIČ-KAVuR 2012, 406, Sl. 2/Fig. 2); 2. Stare gmajne III (dokumentált h: 3,3 m, VeLUŠČEK-VERANIČ-ČUFAR 2009, 230, Sl. 9.7/Fig. 9.7); 3. Stare gmajne II (dokumentált h: 1,5 m, ERIČ 2008, 14, Sl. 10); 4. Za strugo (sz: 1,2 m, DirJeC 1990, 137, Sl. 7); 5. Matenski I (h: 9.3 m, ERIČ 2008, 15, Sl. 12)

Fig. 13. Prehistoric logboats from the Carpathian Basin (Slovenia): 1. Hotiza (1: 9,34 m, ERIČ-KAVUR 2012, 406, Sl. 2/Fig. 2); 2. Stare gmajne III (recorded 1: 3,3 m, VELUŠČEK-VERANIČ-ČUfAR 2009, 230, Sl. 9.7/Fig. 9.7); 3. Stare gmajne II (recorded 1: 1,5 m, ERIČ 2008, 14, Sl. 10); 4. Za strugo (w: 1,2 m, DirJEC 1990, 137, Sl. 7); 5. Matenski I (1: 9.3 m, ERIČ 2008, 15, Sl. 12) 


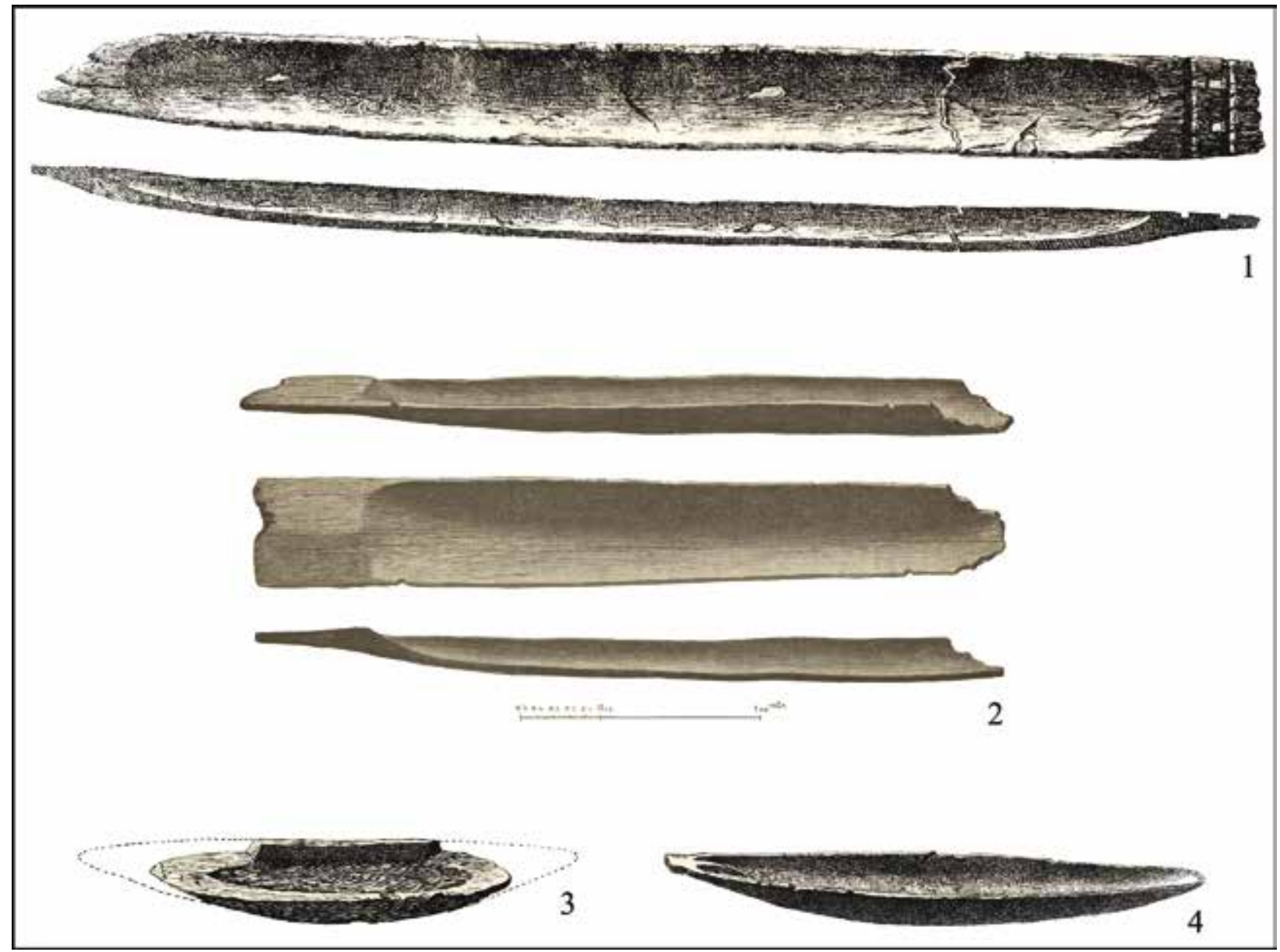

14. kép. Őskori bödönhajók és fából készült csónakmodellek a Kárpát-medencéből (Bosznia-Hercegovina): 1. Donja Dolina (h: 12,38 m, TruHelka 1906a, Tabla LX/1-2); 2. Donja Dolina (h: 4,7 m, TruHelKa 1904, 59, Fig. 35); 3. Ripač (h: 0,23 m, ĆuRČIĆ 1908, 160, Sl. 2); 4. Donja Dolina (h: 0,33 m, TRUHelKa 1906b, 220, Sl. 54)

Fig. 14. Prehistoric logboats and wooden logboat models from the Carpathian Basin (Bosnia and Hercegovina): 1 . Donja Dolina (1: 12,38 m, TruhelKa 1906a, Tabla LX/1-2); 2. Donja Dolina (1: 4,7 m, TruHelKA 1904, 59, Fig. 35); 3. Ripač (l: 0,23 m, ĆuRČIĆ 1908, 160, Sl. 2); 4. Donja Dolina (1: 0,33 m, TRUHELKA 1906b, 220, Sl. 54)

natkozólag a leltárkönyv egyáltalán nem szolgál támponttal, utóbbiból (legalább) öt darabot is felsorol (42.18-21,23/1924). A fennmaradt két agancseszköz formája nem hasonlít a csónak rajzain látható tárgy alakjára.

\section{Összefoglalás}

A fent idézett források alapján bizonyos, hogy 1923. október elején, majd egy évre rá, 1924. október második felében egy tudományos szempontból „páratlan” leletet hoztak felszínre a tószegi Laposhalmon, amely a korabeli napi- és havilapokban, noha rövid életư, de jelentőségéhez méltó visszhangot kapott. Régészeti hordereje keltezése fényében érthetó meg igazán, mivel vele Magyarország egyik legkorábbi csónakleletét, avagy ahogy a Pesti Hírlap fentebb már idé- zett sorai fogalmaznak, "a kulturhistória egyik legrégibb emléket ástuk ki". Stratigráfiai alapon a tell korai időszakára, a 20-as évek ásatásain kiásott leletanyag tanúsága szerint annak nagyrévi jellegú kerámiával jellemezhető, kora bronzkori periódusára datálható - bár az sem kizárt, hogy régészeti kontextusának idejénél akár jóval korábban is készülhetett. ${ }^{95} \mathrm{~A}$ kora bronzkori Alföld hidrológiai viszonyai közepette a vízi jármúvek nélkülözhetelen használati (közlekedési, szállító-, illetve halász-) eszközök lehettek, ${ }^{96}$ éppen ezért meglepő, hogy a térségból egyáltalán nem, tágabb értelemben véve a Kárpát-medencéből pedig csak szórványosan ismerünk a tószegi

95 Erre számos példát találunk, 1. LANTiNG 2000, 627.

96 L. különféle két- és háromdimenziós ábrázolásaikat a korabeli anyagi kultúrában: BADER 1978, 104, Pl. XCII/21; KISS 2002, 60, 63-65, 2. kép; Kiss 2007, 121-123, pl. XXIV; OrAVECZ 2011; ORAVECZ 2013 stb. 
tellel egykorú, csónakként értelmezhető leleteket (13-14. kép)..$^{97}$

Bár a tanulmány szövege a leletet gyakran csónakként, illetve bödönhajóként nevezi meg, annak eredeti funkcióját a rendelkezésre álló adatok alapján teljes bizonysággal ma már nem lehet meghatározni. A csónakként való azonosítás az egykori ásató régészek véleményét tükrözi, akik következtetéseiket részben már ellenőrizhetetlen megfigyeléseikre alapozták. Bár Tompa és Márton egyaránt egy vízi jármú mellett érvelt, ami a tárgy megismerhető morfológiai, készítéstechnikai és méretbeli jellegzetességei alapján egy ésszerú magyarázatnak túnik, egyéb használati lehetőségek is felmerülhetnek (ahogy már akkortájt is felvetődtek). ${ }^{98} \mathrm{~A}$ tárgy feltáráskor dokumentált fizikai vonásait (pl. állapotát) és régészeti kontextusát (tellen belüli helyzetét, leletösszefüggéseit) különféle kulturális és természetes képződési folyamatok eredményeként foghatjuk fel. Attól függően, hogy ezen tényezők közül melyeknek tulajdonítunk nagyobb jelentóséget, a lelet funkcióival és életútjával kapcsolatban többféle forgatókönyv is rekonstruálható. ${ }^{99}$

A legkézenfekvőbb lehetőség, hogy az ásatók véleményét elfogadva a leletre bödönhajóként tekintsünk. Ez az elgondolás a tárgy ismert fizikai vonásaival összhangban áll. ${ }^{100}$ Bár a készítéséhez felhasznált nyersanyag (fúz) tekintetében, annak fizikai tulajdonságaiból adódóan, felmerülhet a kérdés, hogy hosszú távon alkalmas volt-e ilyen feladatra, a jelenség nem egyedülálló: noha ritkán, de különböző korokban és helyeken is dokumentálták fúzfa törzséből készült bödönhajók használatát. ${ }^{101}$

Amennyiben a tárgyat csónakként kezeljük, régészeti kontextusa és fizikai tulajdonságai alapján földbe kerülésének körülményeit illetően legalább kétféle forgatókönyv is felvázolható. Egyik lehetőség, hogy a bödönhajó hosszantartó, rendeltetésszerủ használat (mérete alapján valószínúleg halászat ${ }^{102}$ ) következtében egyszerúen

\footnotetext{
97 Magyarország területén talált őskori vízi jármúvekhez l. még BAKAY-KALICZ-SÁGI 1966, 76 (Keszthely, 1); SzILAS 2003, 67; a Kárpát-medence peremterületeiról ismert őskori bödönhajókhoz l. többek közt TRUHELKA 1904, 57-60, fig. 35; TRUHELKA 1906a, 102-106, tabla LIX, LX/1-3; TRUHELKA 1906b, 220, sl 54; ĆURČIĆ 1908, sl. 2; DiRJEC 1990, 137, sl. 7; LANTING 2000, 643; ERIČ 2008, 14-15, 36, sl. 10-13; VELUŠČEK-VERANIČ-ČUfAR 2009; ERIČ-GASPARI-KAVUR 2012, 398, 402; ERIČ-KAVUR 2012.

98 HOLLENDONNER 1925, 201 (odvas fatörzs?).

99 ADAMS 2001; VAN DE NOORT 2011, 201-227.

100 McGraIL 1987, 57 fizikai szempontjai közül legalább 2-3 teljesül.

101 ANDrÁsfalvy 1973, 33; McGrail 1987, 26; GRÁFIK 1993, 379 (Bogyiszló); ARNOLD 1995, 40-41, 170 (Kuzawka); ARNOLD 1996, 31; Rogers 2009, 64 (Michalovce).

102 OssowsKi 2000, 64.
}

tönkrement és sorsára hagyták. ${ }^{103}$ Tompa Ferenc szerint felfedezésének színhelyére (másodlagos kontextus) már a Tisza áradása sodorhatta, ahol azután iszappal beborítva hosszú időre el is takarta azt „,a később föléje települő ember szeme elől". ${ }^{104}$ Ezen olvasattal az ásatók által megfigyelt rétegtani viszonyok (l. árvízi hordalékréteg), a „lélekvesztó" lelőhelyen belüli helyzete (l. a tellnek a középső és feltehetően a kora bronzkorban is központi, vízparttól távol eső részéról került elő), valamint rossz fizikai állapota egyaránt könnyen összeegyeztethetők, a törzs belsejében talált in situ leletekre ugyanakkor nem nyújt kellően kielégító magyarázatot.

Utóbbira egy némileg módosított forgatókönyv adhat választ. Ennek értelmében a tószegi csónak nem tartós használat után, hanem sokkal inkább még élete kezdeti szakaszában került föld alá. Egy félig kész, befejezetlen, esetleg rontott darab lehetett, amit "a megrémült óslakók" hagytak hátra, feltehetóen készítésének helyszínén. A tárgy belsejében talált, füz faragására is alkalmas agancskalapács könnyen értelmezhetó a fatörzs megmunkálásának in situ talált eszközeként, a csónaktest sérülései pedig felfoghatók e munkafolyamat során vétett hibákként. Ezt az elképzelést a csónak lelóhelyen belüli pozíciója (településen belül, vízparttól távol) sem cáfolja, lévén a törzs kidöntésének, majd legallyazásának és előkészítésének helyszíne nem feltétlenül esett egybe kivájásának és végső megmunkálásának színhelyével. ${ }^{105}$

Természetesen megeshet, hogy mivel „az ötezer éves lélekvesztó most bizony nem mutat csónakformát" (Szózat), az ásatók tévedtek, és az előkerült lelet nem bödönhajó, hanem egy hasonló technikával, de más céllal készült tárgy volt. Méretei és morfológiája alapján akár teknőként, vályúként vagy (a benne talált fogsor fényében) esetleg koporsóként is értelmezhetjük. ${ }^{106}$ Előkerülési helyét, attól függóen, hogy a rajta látható sérüléseket, illetve a benne talált agancsszerszámot a kifaragás, a mindennapi használat vagy éppen a javítás valamely munkafolyamatával hozzuk kapcsolatba, előállításának és elsődleges felhasználásának helyszíneként egyaránt felfoghatjuk. Noha a fennmaradt metszet- és felszínrajzok nem sok támpontot adnak e tekintetben, a szöveges beszámolók alapján környezetéról egy

\footnotetext{
103 A scenárióhoz l. AdAms 2001, 293-295; Rogers 2009, 219.

104 TOMPA 1924.

105 Bödönhajók előállításának folyamatáról és e folyamat változó tereiról l. MCGRAIL 1987, 59-64.

106 McGrail 1987, 56-57; Mowat 1998, 30; koporsókhoz 1. TRUHELKa 1904, 76-77, fig. 58; DANI-V. SZABÓ 2004, 97-98; VAN DE NOORT 2011, 204-205.
} 


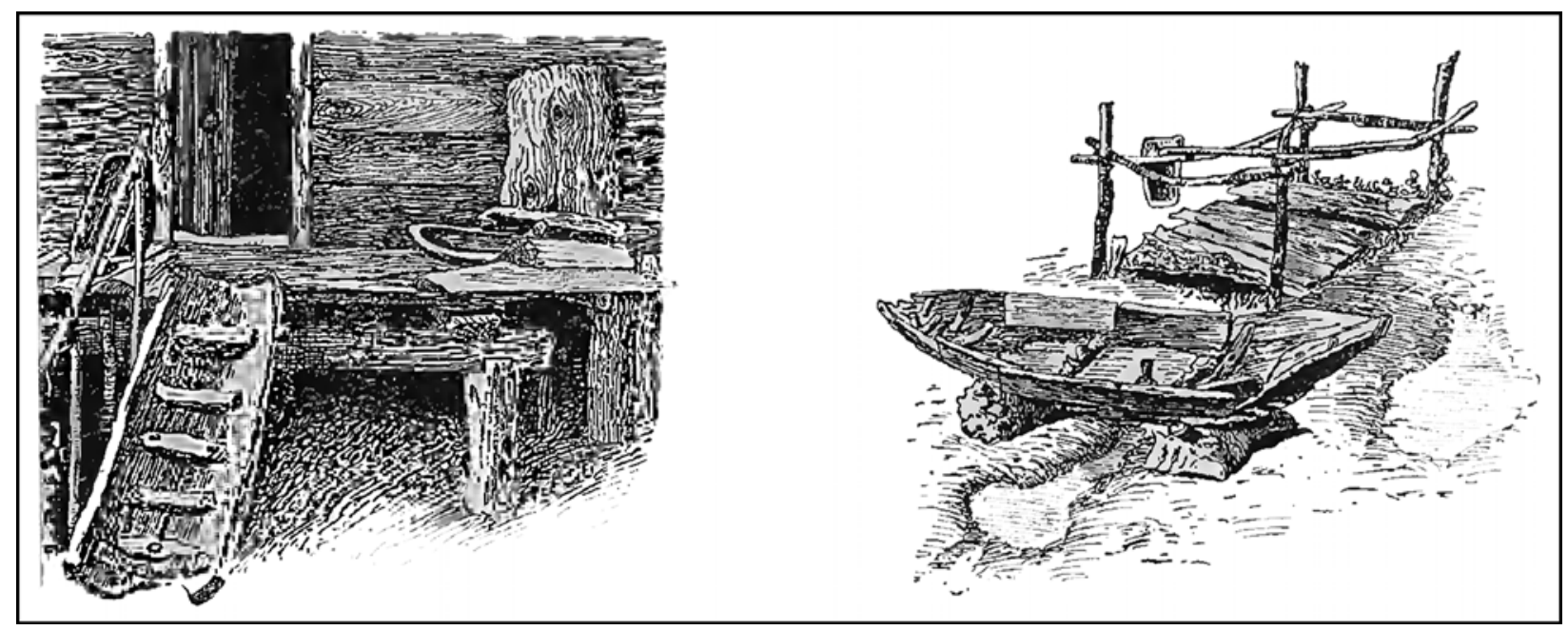

15. kép. Újrahasznosított csónakok: néprajzi példák Bosznia-Hercegovinából (ĆURČıć 1912, 501, Figs 8-9)

Fig. 15. Recycled boats: recent examples from Bosnia and Hercegovina (ĆURČIć 1912, 501, Figs 8-9)

olyan kép rajzólodik ki, amely szerint az nem egy érintetlen, használaton kívül álló zóna, hanem inkább egy olyan településrész lehetett, amelyet a tell lakói aktívan, bár időről időre változó, a korabeli feltárási technikákkal nem könynyen dokumentálható céllal használtak.

Bár a régészeti anyag tesztelésükre kevés támponttal szolgál, akár összetettebb történet is elképzelhető. Nem kizárt, hogy a tárgy eredetileg tényleg csónaknak készült és akként is használták, miután azonban a rendszeres igénybevételtől tönkrement, új jelentést és rendeltetést kapott. Ennek során kerülhetett későbbi felfedezése helyszínére, ahol újrahasznosították (15. kép). ${ }^{107}$
A belsejében talált agancsbalta talán már az átértelmezési folyamat része volt, ami ugyanakkor az árvíz és más depozíciós folyamatok következtében befejezetlen maradt.

A lehetőségek sokasága között valahol ott lapul a valós változat. Ugyan a lelet élettörténetével kapcsolatban továbbra is számos kérdés megválaszolatlan - nem tudjuk, hogy pontosan mire használták, ahogy azt sem, hogy életének mely fázisában és milyen folyamatok eredményeként került későbbi megtalálásának színhelyére - örömteli felfedezésének tudománytörténeti jelentőségén ez mit sem halványít. ${ }^{108}$

\section{FÜGGELÉK*}

\section{A felfedezést követő első beszámolók}

Szózat 6. évf. 242. sz. 1924. október 31. 10.:

\section{B. L.}

\section{Az ötezeréves tiszai halász}

A Krisztuselőtti harmadik évezredból való kéregcsónakot találtak Tószegen

A szolnokmegyei Tószegen a Nemzeti Muzeum hoszszabb idő óta folytat ásatásokat. A falu határában lévő Laposhalom nevú emelkedés, mely valaha a Tisza árterületéhez tartozott, bőséges lelőhelye a prehisztorikus ember kulturcikkeinek. A muzeum ásatásainak során most legutóbb olyan leletre bukkantak, mely ha minden kétséget kizáróan beigazolódik, hogy abból a korból való,

${ }^{107}$ A vízi jármúvek profán újrahasznosításáról, illetve szándékos megrongálásáról és deponálásáról l. ADAMs 2001, 294296; ROGERS 2009, 219-221; VAN DE NOORT 2011, 217-221. A funkcióváltásra hoz példát ĆURČıć 1912, 501, fig. 8-9; GRÁFIK 1993, 374 . melybe lelőhelye és a felette lerakódott rétegek sorolják, párját ritkítja az egész világon. Tompa Ferenc muzeumi örnek ugyanis sikerült egy őskori kéreg csónakot, egy kanoe porladó maradványait a kőkori lerakódásokból, tiszai hordalékból kiemelni. A csónakot a hozzájatapadt földtömeggel együtt kockánkint vágták ki, miután a tisztogatás alkalmával egyszerü érintésre porladt széjjel. A vele kiásott földtömeggel együtt két méter hosszu vastag deszkaládá-

108 Köszönettel tartozom Szathmári Ildikónak, hogy Tompa Ferenc csónakról szóló, kiadatlannak hitt kéziratára felhívta a figyelmemet, és így elindította a kutatást. Köszönöm az MNM RA munkatársainak, Szende Lászlónak és Komiszár Szilviának az 1920-as évek ásatási dokumentációinak átnézésében nyújtott segítségét. A tanulmányhoz fúzött megjegyzéseiért és az illusztrációk elkészítésében nyújtott segítségéért Fejér Eszternek tartozom hálával.

* A függelékben közölt szövegek a források eredeti írásmódját követik, az újságokban szereplő helyesírási és formai hibákat, elgépeléseket nem javítottam. 
ba helyezték és igy szalmával kirakott teherautón hozták Budapestre, ahol a rekonstrukció és a további vizsgálatok megejtéséig a muzeum kőrégiségtára folyósóján helyezték el.

A leletről dr. Tompa Ferenc muzeumi őr a következőket mondotta munkatársunknak:

- A tószegi Laposhalomban már régóta folytat kutatásokat Márton Lajos, a Nemzeti Muzeum nyugalmazott őre. A kutatások során a kő és bronzkorszak életét tanusító maradványok, lakóüregek, tüzhelyek, tüzpadok és leletek: kőeszközök, csontárak, szigonyok és rengeteg kerámiai anyag került elő. A Laposhalom hordalékhalom a Tisza áradási területében. Őskori halásztelep lehetett, ezt a rengeteg ott talált halászszerszám, szigonyok, csonthorgok és halszálkák bizonyitják. A telepet még lakták akkor, amikor a viz már onnét letakarodott. Mikor azután a viz szokásos áradásain ráhordta az iszapot, feltöltődött. Ebben a vágásban, ahol a csónakért ásattunk, nem kevesebb, mint hét kulturrétegre találtunk, melyben a kő illetve a bronzkor különböző korszakaiból maradtak fenn emlékek. Az az idő, amit ez a hét réteg lerakódása igénybe vett, körülbelül két ezredévnek felel meg. Két ezredévről ad tehát keresztmetszetet ez a tiszaparti domb.

$\mathrm{Az}$ a réteg, ahol a csónak elfeküdt, számitásom szerint a Krisztus előtti harmadik évezredból való. A múlt évi ásatások alkalmával, amikor körülbelül két és fél méter mélységig hatoltunk a földbe, rátaláltunk a csónak felálló, jellemző orrára. Sajnos, ezt a csücskét, mintegy 40 centiméteres darabot $a$ tavaszi áradás elvitte. A csónak ugyanis rézsutason feküdt a földben és felső vége kulturrétegbe került. Ez a felső vége tönkrement, mert éppen egy tüzpad volt fölötte.

- Alakjából következtetve, mintegy három méter hosszu lehetett. A most kiásott, megmaradt része 187 centiméter. Körülbelül 35-40 centiméter mély volt, de természetesen a felette lerakodott rétegek lenyomták, deformálták, ellapították. Most a megmaradt résznek a legnagyobb szélessége 67 centiméter.

$\mathrm{Az}$ ötezer éves tiszai lélekvesztő most bizony nem mutat csónakformát. Első tekintetre a koporsószerü nagy ládában sötétszürke zsiros földtömegnek látszik, mely a középfelé egy kissé lejt. Ha alaposabban megnézzük, vesszük csak észre, hogy a teljesen földszinü felület egy csónak elkorhadt, parafinnal átitatott belső része. A fenekén egy szarvasagancsból készült kapa van, mellette egy csonttörmelék: fogsor. Mind a kettőnek nagy hasznát lehet venni, mint korhatározónak a lelet korának megállapításánál. A csónak fáját most alapos chémiai vizsgálatok alá veszik, valamint a Laposhalom geologiai viszonyait is ujból pontosan felderítik, nehogy valami az ember, vagy a természeti erők által munkált eltolódás a csónak korára vonatkozólag tévedés szülője lehessen. Az eddigi következtetések, melyek a lerakódott rétegek öszszetételéből vonhatók le, a csónakot ötezer év előtti ritkaságnak mutatják. Hasonlókból a Krisztus előtti harmadik évezredből már találtakfaeszközöket.Salzkammergutban, ahol a sóslé egészen konzerválta ezeket. Facsónakokat is találtak már Dániában, fából kivájt szarkofágokat, melyek hasonló koruak, de nem fakéregből készültek.
Budapesti Hírlap 44. évf. 232. sz. 1924. november 1. 15.:

"(Ötezer éves kéregcsónakot találtak Tószegen.) A Nemzeti Muzeum hosszu idő óta folytat ásatásokat a Tószeg melletti Laposhalmon, a mely az ásatások folyamán őskori halásztelepnek bizonyult. Települési rétegei bronzkori és kőkori tárgyakat hoztak napvilágra. A multévi ásatások során Márton Lajos, a Nemzeti Muzeum nyug. tisztviselője egy kéregcsónak kiálló végére bukkant a kőkori rétegben. A kiálló részt az idei tavaszi áradások elvitték, mig a meglevő, mintegy 180 cm. hosszu töredéket a napokban emelték ki és hozták föl a Nemzeti Muzeumba. A kiemelés munkáját Tompa Ferenc muzeumi ôr végezte, a kinek mérései szerint a csónak mintegy 3 méler hosszu, $67 \mathrm{~cm}$. széles és 35-40 cm. mélységú kanoe lehetett. A kulturréteg, a melyből kiásták, a Krisztus előtti harmadik évezrednek felel meg."

Friss Ujság 29. évf. 231. sz. 1924. november 1. 6.:

„A Nemzeti Muzeum régibb idő óta folytat ásatásokat a Tószeg melletti Laposhalmon, mely az ásatások folyamán őskori halásztelepnek bizonyult. A mult évi ásatások során Márton Lajos egy kéregcsónak kiálló végére bukkant a kőkori rétegben. A kiálló részt az idei tavaszi áradások elvitték, míg a meglevő, mintegy $180 \mathrm{~cm}$. hosszu töredéket a napokban emelték ki és hozták fel a Magyar Nemzeti Muzeumba. A csónak mintegy 3 méter hosszú, $67 \mathrm{~cm}$ széles és 35-40 cm mélységü kanoe lehetett. A kulturréteg, amelyből kiásták, a Krisztuselőtti harmadik évezrednek felel meg."

\section{Új Barázda 6. évf. 232. sz. 1924. november 1. 2.: \\ Ötezeréves kéregcsónakot találtak Tószegen}

A Nemzeti Muzeum régebb idő óta folytat ásatásokat a Tószeg melletti Laposhalmon, mely az ásatások folyamán őskori halásztelepnek bizonyult. Települési rétegei bronzkori és kőkori tárgyakat hoztak napvilágra. A mult évi ásatások során Márton Lajos, a Magyar Nemzeti Muzeum nyugalmazott tisztviselője, egy kéregcsónak kiálló végére bukkant a kőkori rétegben. A kiálló részt az idei tavaszi áradások elvitték, mig a meglevő, mintegy $180 \mathrm{~cm}$. hosszu töredéket a napokban emelték ki és hozták fel a Magyar Nemzeti Muzeumba. A kiemelés munkáját Tompa Ferenc muzeumi őr végezte, akinek mérései szerint a csónak mint egy 3 méter hosszu, $67 \mathrm{~cm}$. széles és 35-40 cm. mélységü kanoe lehetett. A kulturrétég, amelyből kiásták, a Krisztus előtti harmadik évezrednek felel meg.

Magyarság 5. évf. 238. (1137.) sz. 1924. november 9. 7.:

Ötezeréves kéregcsónakot találtak Tószegen

- A Magyarság tudósítójától -

A Magyar Nemzeti Muzeum földszintjének boltíves folyósói alatt néhány nap óta hatalmas láda hever, amelynek tartalma a tudósok körében világszerte nagy érdeklődésre tarthat számot. A benne rejlő arheológiai lelet azonban olyan nagy jelentőségü, hogy a nagyközönség is jogosan érdeklődik iránta.

A magyar arheológusok táborának két szorgalmas tagja ugyanis Tószegen megtalálta az első magyar kőkori 
kéregcsónakot. Az érdekes lelet jelentőségét az a tény fokozza, hogy ezidőszerint páratlanul áll egész Európában.

[Képaláírás:] A tószegi Laposhalom, jobb zugában a kéregcsónak látható

Tószeg kőkori telepét a tudósvilág idestova fél évszázada ismeri. Néhai Rómer Flóris ásatott a Szolnok alatt, a Tiszától mintegy három kilométernyire eső tószegi Laposhalmon elsőül 1876-ban. Ô tárta föl a késóbb rendkivül gazdagnak bizonyult őstelep rétegeit. Két évvel utóbb, 1878-ban zajlott le Budapesten a nemzetközi arheológiai kongresszus, amelyen Pigorini olasz régiségbuvár a tószegi telepet a felsőolaszországi Póvidéki terra marékkal, vagyis telepdombokkal hasonlította össze. Azóta kitünt, hogy Pigorini tévedett s a tószegi szihalom - ahogyan a magyar arheológusok ezeket a telepdombokat nevezik - lényegesen különbözik a tipikus terra maréktól.

[Képaláírás:] Árak, gyürü, késnyél, kőbalták és agyarfüggő a tószegi őstelepből

Rómer Flóris uttörése után évtizedekre megállt a munka Tószegen s az ásatásokat csak 1906-ban kezdte meg újra Márton Lajos dr., a Magyar Nemzeti Muzeum régiségtárának tudós tisztviselője, aki azután megszakitás nélkül nyolc éven át minden nyáron hónapokig mind mélyebbre és mélyebbre hatolt. Sorra fejtette le a telep összes kulturrétegeit, a legfelső, hallstatti, vagyis idősebb vaskori rétegektől a bronzkorimaradványokat tartalmazó rétegeken át le a csiszolt kőkorszak, a neolitkor iparát tartalmazó legalsó rétegekig.

Roppant földmunkát kellett elvégezni, mig valamenynyi réteget lefejtették és tartalmát napvilágra hozták. Remekbe készült bronzkori késnyelek, szarvasagancsszoritók, disznóagyarból készült függők, kőbalták, tüzhelyrácsok, gyürüfoglalók, hálónehezékek, müvészileg megformált, izlésesen diszitett, égetett agyagból készült apró korsók százával, ezrével akadtak a különböző rétegekben. A leletek koronája azonban az a kéregcsónak, amelyre Márton Lajos dr. tavaly, 1923 őszén bukkant. A mélyre ásott domb egyik zugában észrevett egy különös alaku földtömeget s amikor óvatosan föltárta, kitünt, hogy egy korhadó fiatal kőkori kéregcsónak szétmálló darabjai hevernek ott.

[Képaláirás:] $10 \mathrm{~cm}$. magas korsócskák Tószegrōl

A Tisza tavaszi áradásai a domb meredek falából kiálló csónak egyik darabját elsodorták. Ez év nyarán Hóman Bálint dr., a Magyar Nemzeti Muzeum főigazgatója azzal a megbizással küldte ki Tompa Ferenc dr. arheológust, emelje ki a megmaradt darabot a dombfalból és szállíttassa fel a eNmzeti Muzeumba.

Tompa Ferenc dr. Márton Lajossal együtt körültekintő figyelemmel el is végezte feladatát s az érdekes lelet ma már biztos helyen várja kellő konzerválását és felmontirozását.

Tószeg őstelepének ez a korhadt kéregcsónakja a maga nemében páratlanul áll. A svájci (Billersee), a württembergi (Schussenried) és lombardiai cölöpépitményekból és a skót mocsarakból eddig is több őskori csónakot ástak ki, de ezek egytől-egyig egyetlen fatörzsből kivájt monoxylonok, míg a tószegi lelet Márton Lajos és Tompa Ferenc szerint kéregcsónak, tehát olyan vizijárómü, amely legközelebb áll a tipikus kanoekhoz.
[Képaláírás:] Szarvasagancs-szoritó és kapa Tószegről

Informátorunk, Tompa Ferenc dr. szerint a csónak ma már csak 187 centiméter hosszu, de ha hozzávesszük az árviz elsodorta 40 centiméteres darabot, 227 centiméter, tehát jó két és egynegyed méter lehetett. Legnagyobb szélessége 67 centiméter, mélysége pedig 40 centiméter.

A leletet Tószegen karbolineummal impregnálták s most állítják fel. Növénytani szempontból Hollendonner Ferenc dr., a budai Paedagogium tanára vizsgálja meg. A lelet egész jelentőségét azonban csak akkor ismerjük meg, ha megjelenik Márton Lajosnak a tószegi őstelepről készülő terjedelmes monografiája, amelyet ma már egész Európa régészvilága érdeklődéssel vár.

Ha a magyar arheológusok nem küzdenének olyan leküzdhetetlen pénzügyi nehézségekkel, melyek lehetetlenné tesznek minden nagyobbszabásu ásatást, még Csonkamagyarország földje is nem egy meglepetéssel szolgálna a régészek számára. Amig azonban a társadalom nem segit egységesen megszervezett és jól átgondolt akcióval, addig csak a meglevő anyag feldolgozásáról lehet szó, - ujabb leleteket hiába vár a külföld Európának arról a területéről, amely régészeti szempontból a legérdekesebbek egyike.

\section{8 Órai Ujság 10. évf. 240. sz. 1924. november 12. 7.:}

\section{Tószegen kőkorszakból származó csónakot találtak.}

Tószegen, Szolnok közelében az ugynevezett Laposhalmon már 1876-ban régészeti kutatásokat kezdett Róner Flóris, aki ezen a vidéken mar akkor is több értékes leletre bukkant. Majd később 1906-ban Márton Lajos ugyanezen a helyen folytatott ásatásokat. Mig végre ez év októberében Marton és dr. Tompa Ferenc közös munkájával egy $108 \mathrm{~cm}$. hosszu csónakmaradványra akadtak. A csónak a Krisztus elötti III-ik évezredböl származik, tehát körülbelül 5000 éves lehet. A lelet a fiatalabb kókorszak végéröl származik, amint azt a felette és körülötte talált kulturmaradványok bizonyitjak. Ez a Laposhalom ugy keletkezhetett hogy a Tisza többizben megáradva, elüzte a partján élő halászembereket, akik aztán mindenféle edényeket és csonteszközöket, szóval kulturmaradványokat hagytak hátra, amit a Tisza által odahordott iszap es homok visszatértükkor már eltakart. Ezért van az, hogy az itt talált kulturmaradványokat ugynevezett értéktelen rétegek választják el egymástól. Ez a lelet nagy fontossággal bir a Nemzeti Muzeum régészeti osztályára nézve, mert még eddig Magyarországon csónakot nem találtak, külföldön is csak ott, ahol cölöp-épitmények voltak a közelben. A Nemzeti Muzeumban most vizsgálják meg, hogy a csónak fából vagy kéregből van-e készitve.

\section{Nemzeti Ujság 6. évf. 243. sz. 1924. november 16. 20.: \\ A tószegi óskori csónak}

Írta: Tompa Ferenc dr., muzeumi őr

Már megemlékeztünk a Tószegen elókerült őskori csónakról, mivel azonban ez a lelet annyira figyelemre méltó, hogy feltétlenül megkivánja a nagyközönség számára való szakszerü ismertetést is, szükségesnek láttuk a lelet jelentőségéről és a lelő körülményekról az alábbiakban rövid tájékoztatást adni s ezért Tompa Ferenc dr. muzeumi örhöz, a fölkutatás vezetöjéhez fordultunk, aki az alábbi nagyérdekü cikket bocsátotta a Nemzeti Ujság rendelkezésére. 
A fiatalabb kőkorszakból, réz- és bronzkorból származó cölöpépítményekból külföldön elég nagy számmal kerültek már elő őskori csónakok, melyeket az őskor embere főként tölgyfából, ritkábban füzfából égetett, illetóleg vájt ki s amint egyik-másik lelet bizonyitja, még ülőpaddal is ellátott. Hasonlóak voltak ezek a csónakok a Balatonon még a mult században is ismert, egy törzsből kivájt ugynevezett "bödön” csónakokhoz, sőt a készités módja sem különbözhetett ezekétől. A kinagyoló munkát itt is a tüz végezte, tehát kiégették a belsejét, az utolsó simitásokhoz pedig kőeszközöket, illetve a bronzkorban már a bronz baltákat használták. Az őskori ember megyfigyelő képessége jóval fejlettebb volt a mienkénél. $S$ ahogy a természet megfigyelése tanitotta meg a kőeszközök csiszolására, ugy a természeti jelenségek megfigyelése adta meg az impulzust a csónaknak, mint szállitó eszköznek készitésére is. A víz mellett tanyázó őskori ember áradások alkalmával gyakran látott uszó fatörzseket, iparkodott tehát azokat praktikusan saját szükségleteinek szolgálatába állitani. Több ilyen fatörzset hánccsal össze is kötözött, azaz tutajt készitett, megismerte tehát a legprimitivebb vizi alkalmatosságot. Amikor a fatörzset kivájja és ugy ereszti vizre, ez már a megismerések sorozatában feltétlenül haladást jelent és itt a megfigyelés mellett a tapasztalatait és próbálkozásait is érvényesiti.

[Képaláírás:] A Loch canmori csónak, melynek hü mása a most kiásott tószegi csónak.

A ma élő primitiv népek is ismerik és használják a vájt csónakot, de miként Amerika indiánjai, kéregből is készitenek könnyü és magukkal hordható kanoét, Polinézia lakosainál még a tutajt is megtaláljuk.

A víz felett, vagy áradási területeken épült cölöpépítmények leletei között szinte természetes, hogy előkerül a fatörzs-csónak, az „Einbaum” is. A svájci Bielersee-ben már kettőt is találtak, ép igy Robenhausenben és a Chalain-tóban is. Németországban sem ismeretlen, példa rá a Schussenriedben és Koselben talált kőkori csónaktöredék. Lombardiában Mercuragoból került ilyen elő. Franciaországban a Saint Julien sur Cher-ben és a Saint Valéry-ben találtakon kívül, melyek közül az utóbbit a Somme mellett, mint mi most a tószegit, a magas partban lelték. Dechelette még 15 csónakleletet ismer.

Skócia és Irország tavai és mocsarai azt mondhatnánk, szinte bővelkednek a kisebb-nagyobb formáju őskori „bödönök"-ben. Egy párat a jellegzetesek és nevezetesebbek közül jónak látok mégis megemliteni.

Elsősorban mindenesetre a Loch Canmor-ból evezővel együtt előkerült csónaktöredéket, mely formájára és állapotára nézve a legjobban hasonlit a mi leletünkhöz, sőt bátran mondhatjuk, hogy annak szakasztott mása. Többékevésbé jótartásu leleteiról lett nevezetes a Loch Arthur, a Loch Owel, a Loch of Leys, Loch of the Clans, Loch of Sanquar, Loch Na Mial, míg a Loch Dowaltonban magában öt csónakot találtak és ugyancsak több csónak maradványait találták meg a Loch of Kilbirnieben is. A Bienne-tóban még hozzá egyet kővel rakottan találtak, ime a bizonyság, hogy szállitásra is használták. Az emlitetteken kívül Nithsdale, Dumfriesshire, Lochspoots, Buston, Glasgow ma már ugyancsak nevezetes őskori csónaklelőhely. De ismerik a csónakot a Déli-tengerpart vi- dékén is ép ugy, mint fenn Skandináviában, hol a bronzkori csónakok képeit a sziklarajzok is megőrizték.

Magyarországon azonban ez az első ilyennemü őskori lelet. Hogy miért nem leltünk idáig, holott őskori leletekben Európának talán egy országa sem oly gazdag, mint épen Magyarország - arra egyszerü a felelet - mert nincsenek cölöpépitményeink. A Fertő-tóban feltételezték valamikor a cölöpépitményeket, de mindent találhattak eddig ott, csak cölöpöket nem. Ma még az a helyzet, hogy hazánkban nem ismerünk cölöpépitményeket. Tószeg sem az, jóllehet a Tisza áradási területébe eső hordalékhalom kulturrétegeiben cölöpöknek a negativjait találjuk s itt-ott benne farostokat is, mégsem volt ez cölöpépitmény, hanem a felszinre épitett sövénykalibák, szurdékok falait támogató és tetózetét tartó cölöpöknek a nyomait találjuk meg.

A mi folyóink és tavaink mellett megtelepült őskori ember is ismerte és használta is bizonyára a csónakot, de mert az ilyen voltaképen szárazföldi, tehát nem lápos telephelyre lerakódott kulturrétegek nem tudták konzerválni e fából készült alkotmányokat, azok nyomtalanul elpusztultak.

A tószegi csónaknak, habár nagyon is korhadt állapotban való, de mégis szerencsés megmaradását annak köszönhetjük, hogy a Tisza áradása következtében iszapréteg temette el, a késóbb rárakodó kultur-és iszaprétegek pedig többször is viz alatt állottak. Emellett feltehetjük azt is, hogy már a kókori halász is bekente valamivel a csónakját, hogy annak tartósságát biztositsa.

A tószegi laposhalom, melyben $\mathrm{kb}$. négy méter magasan váltakozva találjuk a fuatalabb kókorszak, rézkorszak és bronzkor kuturrétegeit a Tisza áradása által odahordott meddö iszaprétegekkel, már eddig is gazdag és igen érdekes óskori anyaggal szaporitotta gyüjteményeinket. Rendszeres feltárását voltaképen Márton Lajos dr. kezdte meg, aki nyugalombavonultával sem hagyta abba tószegi kutatásait. Az 1923. év őszén Bella Lajossal végzett ásatás alkalmával a legalsó, fiatalabb kőkori rétegben bukkant rá a csónak egyik részére, míg az idei közösen végzett ásatásunk meghozta az eredményt és feltártuk a legelső magyarhoni őskori csónakot. A már tavaly előkerült részból sajnos az idei áradás elhordott egy darabot, igy a ránkmaradt rész egy körülbelül két méter hosszu töredék. A csónak rézsutosan feküdt, dereka már egy fölötte levő kulturréteggel érintkezett, igy a másik felét, mely legalább olyan hosszu lehetett, nem sikerült megtalálni. Feltevésünk különben is az, hogy egy már megrongált csónakot temetett itt el az árviz hordalék, mely azt teljesen eltakarta a föléje települő őskori ember szeme elöl. Egyébként a csónakot magában rejtő 4 méteres földrétegben hét egymás fölött lévő kulturréteget találtunk teljesen zavartalan állapotban, melyeknek zavartalanságát László Gábor dr. főgeologus is konstatálta. Ezekből most is szép számban kerültek elő az őskori lakások és tüzpadok maradványai, a már ismert eszközök kiséretében, ezenkivül az egyik tüzpad mellett vagy négy marékra való pörkölt gabona. A csónakot, mely ugyancsak vájt csónak, de erősen korhadt állapotban, meglehetős nehézségek árán felszállitottuk és most igyekszünk gyüjteményünk számára konzerválni. 
A magyar praehistoria tehát egy ujabb fontos lelettel és ismerettel szaporodott, és ezenfelül egy tanulsággal is. Ásatást csak szakismerettel, a legnagyobb körültekintéssel, lelkiismeretességgel és a lelö körülmények pontos megfigyelésével végezhetünk. Ásatásokra pedig szükség van, mert az őskor kutatója nem az iróasztal mellett, hanem csak ásatásokból gyarapithatja ismereteit, de nem nélkülözheti az ásatásokat a hazai római kori és népvándorláskori kutatás sem, mert ezekből nemcsak a régészet, hanem a történelemtudomány is lépten-nyomon tanul. Az ásatások töltik ki épen ezen korokra nézve tudásunkban a hézagokat, kényszeritenek bennünket nem egyszer nézeteink megváltoztatására, tisztitják és bővitik tehát archeologiai és históriai fogalmainkat. Ma a Nemzeti Muzeum anyagiakban szegény, hogy feladatának ebben az irányban is kellőképen megfeleljen. $\mathrm{Az}$ az intézmény, amely a nemzet hü fiainak önzetlen támogatásával állitotta fel ma már büszkeségünket jelentó gyüjteményeit, kell, hogy most is, ebben az irányban is, ugyanott támogatásra találjon.

Pesti Hírlap 46. évf. 244. sz. 1924. november 16. 39.: Értékes őskori leletre bukkantak Laposhalmon. Fakéreg-csónak a praehisztorikus időkből. A Laposhalmon még a hetvenes években megkezdett ásatások első nagyjelentőségü eredménye.

- A Pesti Hirlap tudósitójától. -

Magyarország, mint ismeretes, bő és jóformán kiaknázatlan területe az archeológusoknak. A Balácza-pusztai római telep, Velemszentvid, Bodrogkeresztur, Fehérvár, nagy lelőhelyek. Ezek az archeológiai területek azonban a histórikus idők, a népvándorlás nyomait őrzik fegyverek, házieszközök, csatatéri rekvizitumok és más tárgyak alakjában.

Az ország ásatásra alkalmas helyei közt sokkal nagyobb jelentőségú a szolnokmegyei tószegi Laposhalom, ahol már történeti idők előtti leletek is kerülnek felszinre. A Laposhalomnak nevezett emelkedés ugyanis egy praehistórikus, óskori lakótelep, ahonnan az évtizedek óta tartó ásatás, - már a hetvenes években kezdték el ennek a Tisza áradási körletébe tartozó területnek a kutatását -, már eddig is számos, az ősember településére jellemző leleteket eredményezett.

A kutatásokat dr. Márton Lajos muzeumi ơr végezte ezen a területen, mely az őslakók tiszai halásztelepe lehetett, emellett szólnak a négy méter magas iszap- és sárrétegből kiásott árak, szigonyok, ugynevezett harpunák és különféle hálónehezékek. Ezeken kivül találtak itt bronzés vaskorszakbeli emlékeket is, a Muzeum kőrégiségtárának e korokra jellemző csonteszközei, kerámiai anyagjai, kő- és bronzbaltái, bronzsarlói, bronz öntőmintái jórészt innen valók. A telep nagyobbfontosságú leletei azonban azok a részben ép, részben töredékekben lévő tüzpadok és tüzelőhelyek, melyeket a parti lakóüregekben találtak $\mathrm{s}$ melyek révén az archeológusok pontos és hü képet nyertek a lakótelepekről.

Az itt folyó szorgos kutatások során dr. Márton Lajos és dr. Tompa Ferenc muzeumi őrök nemrégen egy olyan leletre találtak, mely ritkaságát és régiségét tekintve a Nemzeti Muzeum legbecsesebb tárgyai közt foglal helyet.
A lelet egy fakéregből készült kókorszakbeli csónak 180 centiméteres töredéke, melynek jelentőségéhez nagyban hozzájárul az is, hogy a külföld muzeumainak őskori leletekben gazdag gyújteményeiben csupán három példányt őriznek belöle.

A leletről dr. Tompa Ferenc muzeumi őr munkatársunknak a következőket mondotta:

- A Tószeg határában lévő Laposhalmon már évtizedek óta kutat a Nemzeti Muzeum, melyet egyenesen erre a célra béreltünk ki. Itt, a Tisza hordalék-iszapjával feltöltött hét egymásra következő kulturrétegből már eddig is nagymennyiségú lelet került felszínre. A multévi ásatások alkalmával a legalsó kulturréteg alatt, négy méternyi mélységben, egy kéregből készült csónak kiálló csücskére bukkantunk, melynek kiásására most került sor.

- Feltevésünk szerint a rongált és sérült állapotban lévő csónakot a Tisza egyik áradásakor a megrémült őslakók hagyták ott, melyet aztán a Tisza iszapja elborított $\mathrm{s}$ felette ujabb rétegek rakódtak le. Ezeken az ujabb rétegeken ujabb település történt, ezekben a rétegekben talált leletekről, a csónak fekvéséból s a vele kapcsolatos földből, edényekről, szarvasaggancsból készült baltákról arra következtetünk, hogy evvel a lelettel a kulturhistória egyik legrégibb emléket ástuk ki: a csónak a csiszolt kőkorszak fejlettebb korából való ősember müve.

- A csónak egy részét - sajnos - elvitte a Tisza áradása. A most kiásott töredéke 180 centiméter hosszú és középrészén 67 centiméter szélességú. Teljes ép állapotában körülbelül három méter hosszuságú lehetett.

A nagybecsú lelet jelenleg a Muzem folyosóján fekszik hatalmas deszkaládában, miután bizonyos vastagságú földdel együtt ásták ki, nehogy, mielőtt konzerválása megtörténne, szétmáljon. A kiásása különös gonddal történt: az előre elkészített egyik oldalán nyitott ládát ráhuzták a humusszal elborított csónakra, utána óvatosan aláásták vastagon a földet, s a láda hatodik oldalát alulról erősítették meg. A leletet teherautón hozták a Muzeumba, ahol most óvatosan leszedik a csónakra rétegeződött földet, karbolineummal bekenik, mely tudvalevően profilaktikus szere a fatetveknek és a fakéreg romlását, korhadását előidéző savaknak. Különböző anyagokkal preparáljak még tartósabbá s hiányos részei rekonstruálásával kerül a Nemzeti Muzeum üvegszekrénye alá.

A laposhalmi ásatásokat, mely területet a szakemberek valóságos muzeumnak tartják, jövőre tovább folytatják és erősen remélik, hogy a Muzeum régiségtári gyüjteményét további jelentős leletekkel szaporithatják.

\section{Közmüvelődés 1. évf. 9. sz. 1924. 443.:}

Tószeg határában a laposhalom bőséges lelőhelye a prehisztorikus ember kultúrcikkeinek. Az ottani ásatások során olyan leletre bukkantak, mely szintén párját ritkítja. Egy őskori kéregcsónakot sikerült a kutatóknak a tiszai hordalékból kiemelni. Valamikor őskori halásztelep lehetett itt. A csónak kiásása közben nem kevesebb, mint hét kultúrrétegre találtak, melyben a kó-, illetve bronzkor különböző szakaszaiból maradtak fenn emlékek. Az az idő, amit ez a hét réteg lerakódása igénybe vett, körülbelül két évezredre tehető. 


\section{Hollendonner Ferenc előadása}

Budapesti Hírlap 45. évf. 65. sz. 1925. március 20. 10.:

"(A Tudományos Akadémia) III. osztálya március 23án, hétfőn délután 5 órakor az Akadémia heti üléstermében felolvasó ülést tart, amelynek tárgyai a következők: Konek Frigyes 1. tag: Ujabb adatok a hydrindonok kémiájához cimü közléssorozat II. közleménye. Konek Frigyes l. tag és Janovics Miklós (vendég): A heliotropin (piperonal) hydrindonjának szintézise. Hollendonner Ferenc vendég: A tószegi prehisztorikus faszenek és csónak faanyagának mikroskópi vizsgálata. Előterjeszti: Mágocsi-Dietz Sándor rendes tag. Tokody László vendég: Adatok a Schafarzikit kristálytani és fizikai sajátságainak ismeretéhez. Előterjeszti: Zimányi Károly rendes tag. A felolvasó ülést rövid zárt ülés követi."

Világ 16. évf. 65. sz. 1925. március 20.9.:

Előadások

Az Akadémia III. osztálya hétfőn délután öt órakor az Akadémia heti üléstermében felolvasó ülést tart, melynek tárgyai a következők: Konek Frigyes lev.-tag és Janovics Miklós (vendég): A heliotropin (piperonal) hidrindonjának szintézise. 2. Hollendonner Ferenc vendég: A tószegi praehistorikus faszenek és csónak faanyagának mikroszkópi vizsgálata. Előterjeszti: Mágocsi-Dietz Sándor rendes tag. 3. Tokody László vendég: Adatok a schafarzikit kristálytani és fizikai sajátságainak ismeretéhez. Előterjeszti: Zimányi Károly rendes tag.

Szózat 7. évf. 65. sz. 1925. március 20. 12.:

*Tudományos fölolvasások. A Magyar Tudományos Akadémia III. oszt. márc. 23-án, hétfón délután 5 órakor az Akadémia heti üléstermében fölolvasóülést tart, melynek tárgyai a következők: Konek Frigyes 1. tag: „Újabb adatok a hydrindonok kémiájához" címú közléssorozat II. közleménye. Konek Frigyes 1. tag és Janovics Miklós (vendég): „A heliotropin (piperonal) hydrindonjának szinthézise". Hollendonner Ferenc vendég: "A tószegi praehistórikus faszenek és csónak faanyagának mikroskópi vizsgálata“. Előterjeszti: Mágócsi-Dietz Sándor rendes tag. Tokody László vendég: "Adatok a schafarzikit kristálytani és fizikai sajátságainak ismeretéhez". Előterjeszti: Zimányi Károly rendes tag. A fölolvasóülést rövid zártülés követi.

Az Ujság 22. évf. 66. sz. 1925. március 21. 9.:

(-) A Magyar Tudományos Akadémia III. osztálya március hó 23-án, hétfón délután 5 órakor az Akadémia heti üléstermében felolvaso ülést tart, melynek tárgyai a következők: 1. Konek Frigyes 1. tag: Ujabb adatok a hydrindonok kémiájához" cimü közléssorozat II. közleménye. Konek Frigyes 1. tag és Janovics Miklós (vendég): "A heliotropin (piperonal) hydrindonjának szinthézise". 2. Hollendonner Ferenc vendég: "A tószegi praehistorikus faszenek és csónak faanyagának mikroskópi vizsgálata.“ Előterjeszti: Mágocsi-Dietz Sándor rendes tag. 3. Tokody László vendég: „Adatok a schafarzikit kristálytani és fizikai sajátságainak ismeretéhez." Előterjeszti: Zimányi Károly rendes tag. A felolvasó ülést rövid zárt ülés követi, melyen folyó ügyeket tárgyalnak.
Budapesti Hírlap 45. évf. 68. sz. 1925. március 24. 9.:

"(A Tudományos Akadémia felolvasó ülése.) A Magyar Tudományos Akadémiának III. osztálya hétfőn délután felolvasó ülést tartott. Konek Frigyes 1. tag felolvasta Ujabb adatok a hydrindonok kémiájához cimü közlés sorozatának második közleményét. Konek Frigyes 1. tag felolvasta a maga és Janovits Miklós vendégtől származó synthezisét a hellotropin hydrindonjának. Mágocsy Ditz Sándor dr. r. tag előterjesztette a Hollendonner Ferenc dr. vendégnek A tószegi prechistorikus faszenek és csónak faanyagának mikroszkopikus vizsgálata cimü dolgozatát, amelyben kimutatta, hogy az ebből a korból megmaradt faszenek azoknak a cölöpöknek és tüzelőanyagoknak a maradványai, melyeket a prechistorikus ember az épitkezéshez és tüzeléshez használt. A napilapokban is ismertetett tószegi prechistorikus csónak pedig nem kéreg, hanem egy odvas fúz-törzs, melyet csónakká alakították át, de kéreg nincs rajta. Végül Zimányi Károly r. tag előterjesztette Tokodi László vendégnek adatait a schafarziki kristálytani és fizikai sajátságainak ismertetéséhez."

Pesti Napló 76. évf. 68. sz. 1925. március 24. 14.:

Az Alföld fái ma és a bronzkorban. A Tudományos Akadémia III. osztálya hétfón délután felolvasó ülést tartott. Konek Frigyes levelezőtag felolvasta »Újabb adatok a hydrindonok kémiájához« címú közlés sorozatának második közleményét. Konek Figyes levelezőtag felolvasta a maga és Janovits Miklós vendégtól származó synthezisét a hellotropin hydrindonjánák. Dr. Mágocsy-Dietz Sándor rendes tag elöterjesztette dr. Hollendonner Ferenc vendégnek »A tószegi prechistorikus faszenek és csónak faanyagának mikroszkópikus vizsgálata « címú dolgozatát, melyben a szerzőtől eredő sellakos beágyazással készített metszetek alapján kimutatja, hogy Alföldünkön a neolithikumban és bronzkorban ugyanolyan fákból (szil, tölgy, fúz, nyár, nyír, kőris, mogyoró, som) állottak az erdők, mint amilyenek ma is élnek az Alföldön. A faszenek azoknak a cölöpöknek és tüzelőanyagoknak a maradványai, melyeket a prechistorikus ember az építkezéshez és tüzeléshez használt. Végül Zimányi Károly rendes tag előterjesztette Tokodi László vendégnek adatait a schafarziki kristálytani és fizikai sajátságainak ismertetéséhez.

\section{Említések más alkalomból}

Pesti Napló 76. évf. 69. sz. 1925. március 25. 9.:

B.B., Felbecsülhetetlen értékú ritkaságokat hoztak napfényre a Nemzeti Múzeum tudósai

[...]

Kökorszakbeli tiszai evezôs

Szolnok megyében Tószegi Laposhalmon már évtizedek óta folyik a kutatás. A Tisza hordalékiszapja valóságos kincsesbányája az őskori kutatásnak. Dr. Márton Lajos, dr. Beka Lajos, dr. Tompa Ferenc már eddig is nagyértékú leletre tettek itt szert, eredményt, mely világraszóló, azonban csak nemrégen hozott a Tisza iszapja. Dr. Tompa itt találta meg az őskori halász csonka farostból készült csónakját, mely stearinnal gondosan preparálva a fát enyésztô fatetvek és lúgok ellen, a legféltettebb darabját képezi a múzeumnak. A csónak mellett szigonyokat, halszerszámokat fedeztek fel, melyekből megál- 
lapították, hogy egy őshalászé voltak, aki itt a Tisza partján várta hálóval a kezében, mig a felkelő nap megfürdik a Tisza haldús vizében. Túzhelyeket is ástak fel, lakótélepeit egy ötezeréves törzsnek, akik csöndesen vesztek oda talán éjnek idején a szeszélyes Tisza egy vehemens áradásánál. A túzhelyekben széntörmelékek vannak, lobogott a láng az ôsembernél, mikor meglepte halálhozó iszapáramával a Tisza.

[...]
Pesti Napló 76. évf. 113. sz. 1925. május 20. 5.:

B.B., Nagyszabású ásatásokat készít elő nyárra a Nemzeti Múzeum

$[\ldots]$

Folytatni fogják elsősorban a Szolnok megyében levő Tószeg melletti Laposhalmon már évtizedek óta folyó kutatást, ahol tavaly sikerült először eredményhez jutni: innen ásták ki annak az ötezeréves farost dereglyének csonkított törzsét, melyhez hasonló a világ múzeumaiban csak még egy példányban található.

$[\ldots]$

\section{IRODALOM}

ADAMS, JONATHAN

2001 Ships and boats as archaeological source material. World Archaeology (London) 32:3, 292-310.

ANDRÁSFALVY BERTALAN

1973 A Sárköz és a környező Duna menti területek ősi ártéri gazdálkodása és vízhasználata a szabályozás előtt. Vízügyi Történeti Füzetek 6. Budapest.

ARNOLD, BÉAT

1995 Pirogues monoxyles d'Europe centrale: construction, typologie, évolution 1. Archéologie Neuchâteloise 20. Neuchâtel.

1996 Pirogues monoxyles d'Europe centrale: construction, typologie, évolution 2. Archéologie Neuchâteloise 21. Neuchâtel.

BADER, TIBERIU

1978 Epoca bronzului în Nord-vestul Transilvaniei. Cultura pretracică şi tracică. Bucureşti.

BAKAY KornÉL-KALICZ, NÁNDOR-SÁGI, KÁROLY

1966 Veszprém megye régészeti topográfiája 1. A keszthelyi és tapolcai járás. Magyarország régészeti topográfiája 1. Budapest.

BANNER JÁNOS

1955 Research on the Hungarian Bronze Age since 1936 and the Bronze-Age Settlement at Békés-Várdomb. Proceedings of the Prehistoric Society (Cambridge) 21, 123-143.

BANNER JÁNOS-BÓNA ISTVÁN-MÁRTON LAJOS

1959 Die Ausgrabungen von L. Márton in Tószeg. Acta Archaeologica Academiae Scientiarum Hungaricae (Budapest) 10:1-2, 1-140.

BÓNA ISTVÁN

1975 Die Mittlere Bronzezeit Ungarns und ihre südöstlichen Beziehungen. Archaeologia Hungarica Series Nova 49. Budapest.

1980 Tószeg-Laposhalom (1876-1976). Szolnok Megyei Múzeumi Évkönyv (Szolnok) 1979-1980, 83-107.

1992 Tószeg-Laposhalom. In: Meier-Arendt, W. (Hrsg.): Bronzezeit in Ungarn. Forschungen in TellSiedlungen an Donau und Theiß. Frankfurt am Main 101-114.

CHILDE, VERE GORDON

1927 A Bronze Age village in Hungary: "A thousand years of prehistory”. The Illustrated London News 171. 4614. September 24, 1927. 498.

1929 The Danube in Prehistory. Oxford.

ĆURČIĆ, VeJSIL

1908 Prehistorička sojenica iz brončanog doba u Ripču, kraj Bihaća u Bosni. Glasnik Zemaljskog muzeja u Bosni i Hercegovini (Sarajevo) 20:2, 149-179.

1912 Die volkstümliche Fischerei in Bosnien und der Herzegowina mit besonderer Berücksichtigung der Savefischerei bei Donja Dolina. Wissenschaftliche Mitteilungen aus Bosnien und der Herzegowina (Sarajevo) 12, 490-589.

CSETNEKI JELENIK ELEK

1876a Az óstörténelmi kiállításból. Vasárnapi Ujság (Budapest) 23:36. 1876. szeptember 3. 564, 569.

1876b Az őstörténelmi és embertani kongresszus. Vasárnapi Ujság (Budapest) 23:38. 1876. szeptember 17. 601-603.

DANI JÁNOS-V. SZABÓ GÁBOR

2004 Temetkezési szokások a Polgár határában feltárt középső bronzkori temetőkben. In: Ilon, G. (szerk.):

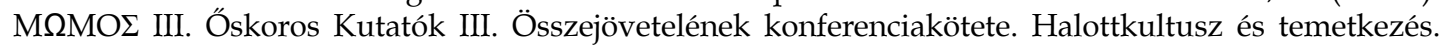
Szombathely - Bozsok, 2002. október 7-9. Szombathely, 91-119. 
DIRJEC, BOŽENA

1990 Čolni deblaki najdeni v zadnjih letih na Ljubljanskem barju. Poročilo o raziskovanju paleolita, neolita in DufFy, PAUL R. eneolita v Sloveniji (Ljubljana) 18, 135-139.

2008 A Körös-vidék bronzkori tell-társadalmai. In: Bóka, G.-Martyin, E. (szerk.): Körös-menti évezredek. Régészeti ökológiai és településtörténeti kutatások a Körös-vidéken. Gyulai Katalógusok 13. Gyula, 107-148.

2014 Complexity and Autonomy in Bronze Age Europe. Assessing Cultural Developments in Eastern Hungary. Prehistoric Research in the Körös Region. Budapest.

ERIČ, MIRAN

2008 Arheologija Ljubljanskega barja: ladje, deblaki, čolniči in vesla. Sezam plovil odkritih na Ljubljanskem barju. Poročila. Zavod za varstvo kulturne dediščine Slovenije, Skupina za podvodno arheologijo 26. Ljubljana.

ERIČ, MIRAN-KAVUR, BORIS

2012 Poznomezolitski deblak iz Hotize / Late Mesolithic logboat from Hotiza. In: Gaspari, A.-Erič, M. (ur.): Potopljena preteklost. Arheologija vodnih okolij in raziskovanje podvodne kulturne dediščine v Sloveniji. Zbornik ob 128-letnici Dežmanovih raziskav Ljubljanice na Vrhniki (1884-2012). Radovljica, 405-408.

ERIČ, MiRAN-GASPARI, ANDREJ-KAVUR, BORIS

2012 Arheološke najdbe čolnov deblakov na Ljubljanskem barju v letih 1990-2010. In: Gaspari, A.-Erič, M. (ur.): Potopljena preteklost. Arheologija vodnih okolij in raziskovanje podvodne kulturne dediščine $\mathrm{v}$ Sloveniji. Zbornik ob 128-letnici Dežmanovih raziskav Ljubljanice na Vrhniki (1884-2012). Radovljica, 397-404.

GASPARI, ANDREJ

2017 Deblak s konca 2. stoletja pr. n. št. iz Ljubljanice na Vrhniki. Študija o ladjah in čolnih predrimskega in rimskega Navporta z orisom plovbe na Ljubljanskem barju med prazgodovino in novim vekom / The late 2nd century B. C. logboat from the Ljubljanica river at Vrhnika. Study on the ships and boats of Preroman and Roman Nauportus with the outline of the navigation on the Ljubljana Marshes between prehistory and the early modern period. Ljubljana.

GRÁFIK IMRE

1993 Bödönhajók, fatörzsból vájt csónakok. Ethnographia (Budapest) 104, 373-391.

GYŐRI IMRE

1924 A magyar földben talált őskori kincsek külföldre vándorolnak. Pesti Hírlap (Budapest) 46:180. 1924.

HAMPEL, JOSEPH augusztus 31. 6 .

1876 Catalogue de l'exposition préhistorique des musées de province et des collections particulières de la Hongrie. Budapest.

HEYWORTH, GILLIAN R.

1984 Tószeg - The Cambridge Collection. Unpublished thesis. University of Cambridge, Lucy Cavendish College. Cambridge.

HOLLENDONNER FERENC

1925 A magyarországi praehistorikus fák és faszenek mikroszkopos vizsgálata. Első közlemény. Matematikai és Természettudományi Értesítő (Budapest) 42, 178-203.

HÓMAN BÁLINT

1929 A Magyar Nemzeti Múzeum öt éve. Jelentés az intézet 1924-1928. évi állapotáról és múködéséről.

KISS VIKTÓRIA Budapest.

2002 Bronzkori csónakmodell Dárdáról. Ősrégészeti Levelek (Budapest) 4, 60-66.

2007 Contacts along the Danube: a boat model from the Early Bronze Age. In: Galanaki, I.-Tomas, H.Galanakis, Y.-Laffineur, R. (eds): Between the Aegean and the Baltic Seas. Prehistory across borders. Proceedings of the International Conference Bronze and Early Iron Age Interconnections and Contemporary Developments between the Aegean and the Regions of the Balkan Peninsula, Central and Northern Europe, University of Zagreb, 11-14 April 2005. Aegaeum 27. Liége, 119-129, P1. XXIIIXXVI.

LANTING, JAN NANNING

2000 Dates for origin and diffusion of the European logboat. Palaeohistoria (Groningen) 39/40 1997/1998, 627-650.

Leighton, MARY-Sørensen, MARIE Louise StiG

2004 Breathing life into the archives: reflections upon decontextualization and the curatorial history of V.G. Childe and the material from Tószeg. European Journal of Archaeology (London) 7:1, 41-60. 
MÁrTON LAJOS

é. n. Die vorgeschichtliche Uferansiedlung Tószeg an der Theiss. I. Bericht über die Ausgrabungen vom Jahre MCGRAIL, SEÁN 1906 bis 1928. Abony. Kézirat. Magyar Nemzeti Múzeum Régészeti Adattár, Ha 2002.XII.136.

1987 Ancient boats in N.W. Europe. The archaeology of water transport to AD 1500. London-New York. MESTORF, JOHANNA

1876 Der internationale Anthropologen- und Archäologen-Congress in Budapest vom 4. bis 11. September 1876. Achte Versammlung. Hamburg.

MOWAT, ROBERT J. C

1998 The logboat in Scotland. In: Pomey, P.-Rieth, É. (eds): Construction navale, maritime et fluviale. Approches archéologiques, historique et ethnologique. Actes du Septième Colloque international d'archéologie navale, Île Tatihou 1994 (Saint-Vaast-la-Hougue). Archaeonautica (Paris) 14, 29-39.

Mozsolics Amália

1952 Die Ausgrabungen in Tószeg im Jahre 1948. Acta Archaeologica Academiae Scientiarum Hungaricae (Budapest) 2, 19-69.

MunRo, Robert M.A.

1882 Ancient Scottish lake-dwellings or crannogs. Edinburgh.

ORAVECZ HARGITA

2011 Bronzkori csónak alakú edény Rakamazról. In: Tóth, E.-Vida, I. (szerk.): Corolla Museologica Kovács Tibor Dedicata. Régészeti Füzetek Új Sorozat IV. Budapest, 403-412.

2013 An Early Bronze Age boat-like representation from Rakamaz, Northeast Hungary. Communicationes Archaeologicae Hungariae (Budapest) 2010-2013, 5-19.

OSSOWSKI, WALDEMAR

2000 Some results of the study of logboats in Poland. In: Litwin, J. (ed.): Down the river to the sea. Proceedings of the Eigth International Symposium on Boat and Ship Archaeology, Gdańsk 1997. ISBSA 8. Gdańsk, $59-66$.

PARET, OSCAR

1930 Die Einbäume im Federseeried und im übrigen Europa. Prähistorische Zeitschrift (Berlin) 21, 76-116.

PIGORINI, LUIGI

1876 Terramare Ungheresi. Bullettino di Paletnologia Italiana (Roma) 2, 230-241.

RADÓ DEZső

1999 Bel- és külterületi fasorok EU-módszer szerinti értékelése. Lélegzet (Budapest) 7-8/Melléklet, 1-12.

RÉTHY GYULA

1908 A tószegi „Kucorgó-halom“ titka. Pesti Hírlap (Budapest) 30:17. 1908. január 19. 35-36.

ROGERS, JASON SAMUEL

2009 How Boats Change: Explaining Morphological Variation in European Watercraft, based on an Investigation of Logboats from Bohemia and Moravia, Czech Republic. PhD dissertation. University of Exeter, Exeter.

SCHALK, EMILY

1981 Die frühbronzezeitliche Tellsiedlung bei Tószeg, Ostungarn, mit Fundmaterial aus der Sammlung SMITH, JOHN ALEXANDER

Groningen (Niederlande) und Cambridge (Groß-Britannien). Dacia (București) 25, 63-128.

1866 On the use of the "Mustard Cap and Bullet” in the North of Scotland. Proceedings of the Society of Antiquaries of Scotland (Edinburgh) 6:1, 255-258.

STRATIGOS, MichAEL

2015 The Royal Yacht. Scottish Crannogs. Diving for history in the lochs of Scotland, May 18, 2015. https:// scottishcrannogs.wordpress.com/2015/05/18/the-royal-yacht/. Hozzáférés: 2019. 03. 04.

STUART, JOHN

1866 Notice of a Group of Artificial Islands in the Loch of Dowalton, Wigtonshire, and of other Artificial Islands or "Crannogs" throughout Scotland. Proceedings of the Society of Antiquaries of Scotland (Edinburgh) 6:1, 113-178.

SZILAS GÁBOR

2003 Késő bronzkori karikalelet a Dunából. Communicationes Archaeologicae Hungariae (Budapest) 67-76. TOMPA FERENC

1924 A tószegi őskori csónak. Nemzeti Ujság (Budapest) 6:243. 1924. november 16. 20.

193725 Jahre Urgeschichtsforschung in Ungarn 1912-1936. Bericht der Römisch-Germanischen Kommission (Berlin) 24-25 (1934-35), 27-127.

TRUHELKA, ĆIRO

1904 Der vorgeschichtliche Pfahlbau im Savebette bei Donja Dolina (Bezirk Bosnich-Gradiška). Bericht über die Ausgrabungen bis 1904 I. Text. Wissenschaftliche Mitteilungen aus Bosnien und der Herzegowina 9. Wien. 
1906a Sojenica u Dônjoj Dolini. Peto otkopavanje god. 1904. Glasnik Zemaljskog muzeja u Bosni i Hercegovini (Sarajevo) 18:1, 99-106.

1906b Sojenica u Dônjoj Dolini. Peto otkopavanje god. 1904. Glasnik Zemaljskog muzeja u Bosni i Hercegovini (Sarajevo) 18:2, 217-228.

VAN DE NOORT, ROBERT

2011 North Sea archaeologies: a maritime biography, 10,000 BC to AD 1500. Oxford.

VELUŠČEK, ANTON-VERANIČ, DEJAN-ČUFAR, KATARINA

2009 Drevaka s koliščarske naselbine Stare gmajne na Ljubljanskem barju / Logboats from the pile-dwelling settlement Stare gmajne at the Ljubljansko barje. In: Velušček, A. (ur.): Koliščarska naselbina Stare gmajne in njen čas. Ljubljansko barje v 2. polovici 4. tisočletja pr. Kr. / Stare gmajne pile-dwelling settlement and its era. The Ljubljansko barje in the 2nd half of the 4th millenium BC. Opera Instituti archaeologici Sloveniae 16. Ljubljana, 223-234.

\section{IN THE FOOTSTEPS OF AN EARLY BRONZE AGE LOGBOAT}

\section{CSABA BODNÁR}

The tell of Tószeg-Laposhalom, as one of the most emblematic prehistoric archaeological sites of the Carpathian Basin, has attracted scholar attention among Hungarian and foreign archaeologists for nearly a century and a half. This interest was also shared by public opinion. In the late 19th century and in the first third of the 20th century, a number of excavations took place on the hill (Fig. 1), most of them followed up by contemporary media. In the most intense period of research (in the 1910s and 1920s), current results were reported almost up-to-date by the metropolitan and provincial press.

In late autumn 1924 modest as well as detailed announcements informed about an "unparalleled" archaeological discovery at the famous "terramare" site: the remains of a wooden prehistoric boat had been unearthed among the cultural layers of the several meters thick tell. Despite the great publicity of this find which still counts as unprecedented from the Bronze Age of Hungary, it has not become an integral part of later professional memory. We do not meet any mention of the find in the academic literature until the 1950s. Although afterwards it has occasionally appeared in publications as a reference, a thorough review of the boat's primary sources has not been performed so far. This article presents the various information available about the boat and, through their critical analysis, aims to reconstruct its physical characteristics, archaeological context, and its subsequent history.

The most abundant group of our sources are the press releases mentioned. The magnitude of the contemporary media coverage of the discovery is indicated by at least 17 releases in 12 different newspapers (see Appendix). Most articles were written in October and November 1924, right after the discovery. Although the information was probably provided by the directors of the excavation, presumably by Ferenc Tompa (curator at the Hungarian National Museum, hereafter HNM), the articles often contain contradictory statements as well. In order to clarify these mistakes and inaccuracies published, even Ferenc Tompa himself considered it necessary to write a brief report on the find addressing the general public.

Beyond the press releases, other remarkable points of reference for the exploration and the archaeological con- text of the boat are the published and manuscript versions of Lajos Márton's (the other explorer's) summary work dealing with his two and a half decades long research at Tószeg, as well as the survived textual and pictoral documentation of the excavations carried out at the site between 1923 and 1928. Although the published text of Márton's monograph largely reflects the content of his original manuscript, the corrections and insertions observed on the manuscript fragments (Fig. 2) slightly modify our perceptions about the creation of his text and thereby also about the circumstances of the discovery. The remaining original excavation diaries, lists of items, horizontal and vertical section drawings (Fig. 8-12), photographs (Fig. 4) and other documents (Fig. 3) related to the excavations of the 1920s - currently held in the archives of the Museum of Archaeology and Anthropology, University Cambridge, of the Groningen Institute of Archeology and mainly in the repository of the HNM - also grant valuable information. Particular attention needs to be paid to a grid booklet (kept in the HNM) filled with some pencil drawings which depict the object precisely recording even its dimensions (Fig. 5).

Finally, further data is available on the boat's physical attributes and later history from the inventory book of the HNM and from Ferenc Hollendonner's study on the macroscopic and microscopic observations of its production technology and raw material.

Regarding the finding circumstances and the post-excavation history of the boat, the written and pictoral sources reviewed are not consistent on every detail, therefore the chain of events outlined here is just one, yet probably the most likely scenario.

There are several sources reporting on the discovery. The most complete description can be found in the manuscript of Márton, but several newspapers have also described this event in detail. Our sources unanimously state that the boat had been found in two parts in two consecutive years. Its first piece, a flat, narrow, heavily rotten piece of wood, was noticed towards the end of the excavation in autumn 1923, after removing several meters of cultural layers. Missing the time need- 
ed, its full exploration was postponed to the next year. Because of the find's bad condition an unsuccessful attempt was made to conserve it still on site - in spring 1924 the flood of the Tisza river destroyed this already uncovered half of the boat. During the short 1924 season a further, approx. 1.8 meter bulk of the object was brought to the surface (Fig. 4). Its heavily rotten condition prevented it from being properly excavated in situ, therefore a "greasy ground mass" with the object in it was sawed out and put into a wooden crate in which it was then transported to the HNM in Budapest.

In the light of the currently available sources the subsequent history of the find is less clear. On the basis of their reports, it can be suspected that short after its discovery the boat was personally visited by several journalists while it had been still waiting for cleaning and conservation in the HNM. On 20th November the find was given an entry in the HNM's inventory book calling it "half of a carved boat". In the meantime, in order to get more reliable data on its raw material and the method of its production, the boat was subjected to "thorough chemical analysis". Samples were taken and sent for microscopic paleobotanical analysis.

Our data on the results of the object's cleaning and conservation process are contradictory. While months after its discovery a newspaper article describes the boat as „carefully prepared [...] and constitutes the most precious piece of the museum", an essentially different image can be outlined in Márton's manuscript. According to his account, after the preliminary cleaning the (anonymous) restorer who was entrusted with the preservation made a mistake and "the object slowly crumbled." In the press, the boat is mentioned for the last time in an article released on 20th May 1925. It can be assumed that if the object had been still existing for a while, it would not have been escaped by reporters' attention. In any case, at the time of a general revison of the HNM's archaeological collection in 1958, there was no longer a physical trace of it. It is difficult to decide on the grounds of the obtainable information, whether it fell victim to the devastation of war (as most of the archaeological material from the 1924 excavation), or it had been destroyed long before due to negligent conservation, or perhaps another reason was responsible for its disappearance.

There is a broad consensus among the sources that the object was in a poor state when it was found. Based on the irregular holes visible in the interior of the find, it was suggested that it had been already damaged when it was buried. In terms of its dimensions, we encounter various data. As for the length of the excavated part in 1924, the descriptions mainly mention $187 \mathrm{~cm}$, and sometimes $180 \mathrm{~cm}$ (Fig. 5. 2; 11. 2). Together with the estimated length of the destroyed $40 \mathrm{~cm}$ piece from 1923 a $227 \mathrm{~cm}$ long object is outlined. However, both excavating archaeologists emphasized that during the exploration not an entire but only a partly preserved boat was identified. The upper, missing half of the object had already been destroyed by the upper layers of the tell. The maximum width of the boat was reported as $67 \mathrm{~cm}$, the depth is $35-40 \mathrm{~cm}$. Somewhat different size is recorded in the drawings mentioned above (Fig. 5. 2).
According to the macroscopic and microscopic observations of Ferenc Hollendonner the samples taken from the object showed the histological characteristics of a deciduous tree, most likely the salix (willow). The age of the willow used for the boat, based on known maximum latitude of the find and on comparative research on recent species, can be estimated as around 46-55 years.

Almost all the sources agree that the find was a human-made artifact. Although both finder believed and emphasized that the object had been once prepared and used as a boat, only few observations were appropriately recorded to support this concept. The majority of the newspaper articles described the find as a bark boat, however, both Tompa and Hollendonner clearly state that it was a dugout carved out from the trunk of a single tree on which there was no crust at all. In the drawings of the object, the body of the artifact is represented as divided by irregularly shaped holes of different sizes (Fig. 5, 2), which could have been the result of overuse, natural decay, or deliberate drilling as well.

Based on the available descriptions and drawings, we cannot accurately reconstruct the shape of the object. The morphological features mentioned in the reports (e.g. "flat, deep, narrow, rounded" body, "typical bow") do not allow a more specific formal classification. On the depictions of the remaining piece there are no traces of internal ribs, dividing walls or other structural elements. Regarding its cross-sectional shape, the size data allows some inferences to be drawn: both reconstructions (Fig. 6) suggest that a whole tree trunk was used to create the object. According to Tompa, the closest parallel of the boat is one of the logboats found in Loch Canmore (Scotland) (Fig. 7), however, he did not give a precise explanation or any specific criterion for this comparison.

There are several inaccuracies in the archaeological literature regarding the stratigraphic position of the boat, which depend on the published version of Márton's manuscript. In his description of the excavation results Márton mentioned the object in a paragraph that describes the features of the 4th cultural level of the site. He depicted it on the surface drawing of the 4 th level in the northern trench of the 1927 excavation (Fig. 8). Our review of the available sources, however, proved that both statements are wrong (e. g. Fig. 9). Both the excavation records and the press releases clearly claim that the object was uncovered on the border of the 1923 and 1924 excavation trenches (Fig. 4;11,2), in an area that was likely to be located in the central zone of the settlement (at least during its Middle Bronze Age phase). Regarding the vertical position of the boat, the profile drawings of 1923 (Fig. 10), the photographs taken during the 1924 season (Fig. 4; 11,2) and the newspaper articles prove that it was found in a layer which had belonged to the early period of the settlement. It appeared at a depth of ca. $4.75 \mathrm{~m}$ to $4.9 \mathrm{~m}$, directly under the 9 th/11th settlement level of the 10/13 level high stratigraphy.

Our sources give us some hint on the objects's closer archaeological context as well. While several articles mentioned it in connection with a "cultural layer", Tompa described its primary context as a flood sediment layer that "completely covered it" before later occupation 
happened. According to the surviving photographs and descriptions, the boat was lying diagonally in the ground, which caused its higher part to be destroyed over time as new settlement layers had been accumulated. On the basis of press information only one archeological feature can be associated with the boat: a "fire bench" (hearth), which was discovered directly above it (perhaps on Fig. 12).

We have only limited information on other objects uncovered together with the boat. Certainly, there are only two finds that have closer contextual relationship to it: a hoe/hammer, made of antler, and a mandibula/teeth. Both were unearthed in situ, in the middle of the vessel. The antler hoe is visible in several drawings which depict it as lying directly on the surface, at the edge of one of the above-mentioned holes (Fig. 5, 2). In the inventoried excavation material of 1924 none of the survived items resemble the shape of the hoe shown on the boat's sketches.

The archaeological significance of its discovery can be understood in the light of the find's dating: it is one of the earliest boat finds uncovered so far in Hungary. The reviewed stratigraphic data reveal that it was associated with the lower layers of the tell, which are characterized by Nagyrév-style pottery and dates back to the Early Bronze Age period of the site (although it can not be excluded that the boat had been created much earlier than what the dating of its archaeological context could suggest). Under the hydrological conditions of the Carpathian Basin in the Early and Middle Bronze Age, watercraft must have been an indispensable means of transport, therefore it is surprising that prehistoric boats are only sporadically known from the region (Figs 13-14).

Although this paper often refers to the artifact as a boat or logboat its original function can not be determined any longer with full testimony. Identification as a boat reflects the views of its explorers who based their conclusions on their already almost uncontrollable observations. Even though both Tompa and Márton argued for a watercraft, which seems to be a reasonable explanation on the grounds of its morphological, technological, and size characteristics, other uses of the object may also arise (as they have already been raised). In relation to the find's biography and the possible functions it has performed during its lifepath, various scenarios can be reconstructed.

The most plausible option is to accept the excavators' opinion and to consider the find as a vessel. In this case, concerning its depositional circumstances, at least two agendas can be outlined. One possibility is that the boat has simply been ruined due to its long-term use (probably as a fishing tool) and left to its fate. Another option is that the dugout was buried underground not after permanent usage, but rather in an early stage of its life. It could have been an unfinished, or messed up artifact left behind by the "frightened indigenous people", presumably at the scene of its production. The hoe found inside the object and suitable for carving a willow trunk can be easily interpreted as an in situ tool for manufacturing the $\log$, and the damages on the watercraft's body can be perceived as mistakes made during the workflow.

Of course, the explorers may have been wrong, and the find was not a logboat, but rather an object made with a similar technique but for another purpose. Based on its dimensions and morphology, we could also interpret it as a tub, a trough, or (in the light of the mandibula found in it) even a coffin.

Although the archaeological record provides little guidance for testing them, even more complex scenarios can be set up. It can not be excluded that the artifact had been originally designed for and used as a boat, however, after a period of regular use, it received a new meaning and a new function. During this process it could have been moved from its original place of usage to a new location where it was recycled, and later discovered (Fig. 15). The hoe found inside could have been part of this re-interpretation process, which, however, remained unfinished due to flooding and other depositional events. 